\title{
EPSPs of Dentate Gyrus Granule Cells during Epileptiform Bursts of Dentate Hilar "Mossy" Cells and Area CA3 Pyramidal Cells in Disinhibited Rat Hippocampal Slices
}

\author{
Helen E. Scharfman \\ Neurology Research Center, Helen Hayes Hospital, New York State Department of Health, West Haverstraw, New York \\ 10993-1195 and Departments of Pharmacology and Neurology, Columbia University, College of Physicians and Surgeons, \\ New York, New York 12402
}

When hippocampal slices are exposed to GABA $_{A}$ antagonists, area CA3 pyramidal cells and dentate hilar "mossy" cells discharge in synchronized epileptiform bursts (Müller and Misgeld, 1991; Scharfman, 1994b). Dentate interneurons are excited simultaneously, but the degree of discharge varies (Scharfman, 1994b). This study primarlly examined the activity of dentate granule cells simultaneous to the epileptiform bursts of pyramidal cells and mossy cells.

EPSPs followed by large GABA $_{B}$ receptor-mediated IPSPS were generated in granule cells during all epileptiform bursts of pyramidal cells and mossy cells, regardless of whether they were evoked or spontaneous. By simultaneous recording it was determined that granule cell EPSPs began several milliseconds after the start of pyramidal cell bursts ( $n=\mathbf{4 8}$ simultaneous recordings) and immediately after the first action potential of a mossy cell burst $(n=77)$. Interneurons were similar to granule cells in the timing of their depolarizations relative to the onset of pyramidal cell ( $n=24$; Scharfman, 1994b) and mossy cell $(n=9)$ bursts.

All excitatory activity was blocked by bath application of the glutamatergic AMPA/kainate receptor antagonist CNQX (5 $\mu \mathrm{M}, n=5$ ), but not the NMDA receptor antagonist D-APV (25-50 $\mu \mathrm{M}, n=9$ ). Granule cell EPSPs were decreased after focal application of CNQX to the molecular layer at a site close to the impaled granule cell $(n=5)$, whereas D-APV had no effect $(n=3)$. EPSPs also decreased after focal application of CNQX to the hilus, in two of four slices tested. The extracellularly recorded EPSP of granule cells was maximal in the inner molecular layer $(n=33)$, the site of the mossy cell axonal plexus. Severing the junction of the dentate gyrus and area CA3 blocked all spontaneous and evoked activity of dentate neurons without affecting burst discharges in area CA3a and CA3b $(n=6)$. None of the excitatory activity of any cell type was affected by cholinergic antagonists (at-

\footnotetext{
Received Jan. 19, 1994; revised Mar. 25, 1994; accepted Apr. 6, 1994.

This study was supported by NIH Grant NS 30831. I thank Drs. Robert Sloviter, Daniel Lowenstein, and Robert Brady for discussion and their comments on the manuscript. I also thank Dr. Simon Neubort for statistical assistance and Mrs. Annmarie Curcio and Mrs. Ruth Marshall for secretarial support. I thank Merck, Sharp and Dohme for their gift of dihydro- $\beta$-erythroidine.

Correspondence should be addressed to Hclen E. Scharfman, Ncurology Rcsearch Center, Helen Hayes Hospital, West Haverstraw, NY 10993-1195.

Copyright (C) 1994 Society for Neuroscience $0270-6474 / 94 / 146041-17 \$ 05.00 / 0$
}

ropine and mecamylamine, $25 \mu \mathrm{M}$ each, $n=5$; pirenzipine and dihydro- $\beta$-erythroidine, $25 \mu \mathrm{M}$ each, $n=5$ ).

The results suggest that there is a glutamatergic, AMPA/ kainate receptor-mediated, excitatory pathway from area CA3 to the dentate gyrus in disinhibited slices. The pharmacological results, analyses of latency, as well as the known axonal projections of the sampled cells, suggest that the excitatory pathway begins within area $\mathrm{CA} 3$ and leads to granule cells via mossy cells. The data also suggest that dentate interneurons are excited by mossy cells, and possibly by pyramidal cells as well. The pathway may be normally undetected because of strong tonic and evoked inhibition in the dentate gyrus, as well as the limited capacity to produce synchronous, repetitive discharge in numerous mossy cells and pyramidal cells when GABAergic inhibition is intact. Such circuitry could form a positive feedback loop when inhibition is compromised, and therefore contribute to epileptiform activity under such conditions.

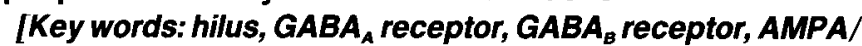
kainate receptor, interneuron, epilepsy, paroxysmal depolarization shift (PDS), hyperexcitability]

Hippocampal circuitry is commonly described in terms of three consecutive monosynaptic excitatory pathways, the "trisynaptic" circuit (Andersen et al., 1971). The first excitatory synapse is between perforant path axons of entorhinal cortical neurons and dentate granule cell dendrites. Granule cells subsequently excite area CA 3 pyramidal cells, and area CA3 cells excite area CAl pyramidal cells. This pathway appears to be circumscribed within repeated units, the hippocampal lamellae, that are organized in parallel along the transverse axis of the hippocampus (Andersen et al., 1971). Several recent reports have argued that there may be important exceptions, or additions, to the trisynaptic circuit (Amaral and Witter, 1989; Yeckel and Berger, 1990). The present study describes one addition to the trisynaptic circuit that became apparent in the course of studies of rat hippocampal slices perfused with the $\mathrm{GABA}_{\mathrm{A}}$ receptor antagonist bicuculline.

The present study arose from the observation that pyramidal cells and dentate hilar "mossy" cells produce synchronized depolarization shifts in the presence of $\mathrm{GABA}_{\mathrm{A}}$ receptor antagonists (Müller and Misgeld, 1991; Scharfman, 1994b). The fact that pyramidal cell bursts preceded mossy cell bursts, and that all bursts were blocked by the excitatory amino acid antagonist 
CNQX, suggested that an excitatory pathway from area CA3 to the dentate hilus might exist, and become evident when $\mathrm{GABA}_{\mathrm{A}}$ receptor-mediatcd inhibition was blocked (Scharfman, 1994b). The hypothesis is supported by studies showing that CA3 pyramidal cells use an excitatory amino acid as a neurotransmitter (Cotman and Nadler, 1981; Ottersen and Storm-Mathisen, 1987), and collateralize in the hilus (Ishizuka et al., 1990; Li et al., 1994).

Given the proximity and the possible synaptic connections of pyramidal cells and mossy cells with neurons of the dentate gyrus, one would predict that granule cells might be affected by the burst discharges of pyramidal cells and mossy cells, either by synaptic or nonsynaptic processes. For example, the large burst discharges of pyramidal cells that occur in disinhibited slices, both in area CA3 and area CA1 (Schwartzkroin and Prince, 1977; Dingledine and Gjerstad, 1980; Wong and Traub, 1983; Hablitz, 1984), could produce nonsynaptic effects by ephaptic interactions (Richardson et al., 1984; Snow and Dudek, 1984; Taylor et al., 1984). Nonsynaptic spread of burst discharge has been reported under various conditions in hippocampal slices (Jeffreys, 1981; Roper et al., 1992).

Synaptic effects of pyramidal cells and mossy cells could be direct or indirect. Pyramidal cells may have indirect effects by exciting different types of cells in the hilus that in turn innervate granule cells. Since hilar cells are immunoreactive for a number of different neurotransmitters and neuropeptides (Kosaka et al., 1985; Köhler et al., 1987; Sloviter and Nilaver, 1987), the indirect effects of pyramidal cells could be excitatory or inhibitory. There also might be little effect on granule cells, if the neurons excited by pyramidal cells do not innervate granule cells or are not activated appropriately to produce their effects.

The synaptic effects of mossy cells are more difficult to predict, because even though mossy cells are immunoreactive for glutamate (Storm-Mathisen and Wold, 1981; Soriano and Frotscher, in press), a clear synaptic effect of a mossy cell on a target neuron has not been demonstrated. Mossy cell axons potentially target both granule cells and nongranule cells, because the mossy cell axon densely innervates the inner molecular layer (Zimmer, 1971; Laurberg and Sørensen, 1981; Swanson et al., 1978, 1981; Ribak et al., 1985; Frotscher et al., 1991), where it makes asymmetric synapses on spines and shafts (Buckmaster et al., 1992), and axon collaterals innervate aspinous elements in the hilus (Scharfman et al., 1990). Therefore, mossy cells may directly excite granule cells and may indirectly affect granule cells via other neurons.

To determine the activity of dentate granule cells during epileptiform bursts of pyramidal cells and mossy cells, we examined granule cells simultaneous to mossy cells and pyramidal cells and asked whether granule cells demonstrated any activity that was temporally associated with mossy cell and pyramidal cell burst discharges. By recording in the presence of bicuculline, and often the $\mathrm{GABA}_{\mathrm{B}}$ receptor antagonist saclofen as well, we predicted that conditions for granule cell excitation would be maximized. Indeed, we found striking excitatory potentials in granule cells during pyramidal cell and mossy cell burst discharges that were blocked by an excitatory amino acid antagonist. The results suggest that the hippocampus contains an excitatory pathway from area CA3 to dentate granule cells, in the opposite direction of the trisynaptic pathway, and that this pathway requires disinhibition for its expression.

Some of the results described below have been presented previously in abstract form (Scharfman, 1993c).

\section{Materials and Methods}

Preparation and maintenance of slices. Preparation and maintenance of slices was sirnilar to previous studies (Scharfman, 1993b). Animal care was in accordance with the guidelines set by the National Institutes of Health and the New York State Department of Health. Adult male Sprague-Dawley rats $(100-200 \mathrm{gm})$ were anesthetized with ether and decapitated. One hemisphere was removed and placed in $4^{\circ} \mathrm{C}$ buffer (in mm: $126.0 \mathrm{NaCl}, 5.0 \mathrm{KCl}, 2.0 \mathrm{CaCl}_{2}, 2.0 \mathrm{MgSO}_{4}, 26.0 \mathrm{NaHCO}_{3}, 1.25$ $\mathrm{NaH}_{2} \mathrm{PO}_{4}$, and 10.0 D-glucose) for $15-30 \mathrm{sec}$. The hemisphere was trimmed to a small block of tissue containing the hippocampus and adjacent structures. Slices $(400 \mu \mathrm{m})$ were cut with a Vibroslice (Stoelting Instruments, Wood Dale, IL) at a $20-45^{\circ}$ angle to the transverse axis of the hippocampus while the tissue was submerged in $4^{\circ} \mathrm{C}$ buffer. Slices were placed immediately in a modified recording chamber (Finc Scicnce Tools, Foster City, CA), where slices lay at an interface of warmed (34 $\left.35^{\circ} \mathrm{C}\right)$, oxygenated $\left(95 \% \mathrm{CO}_{2}, 5 \% \mathrm{O}_{2}\right)$ buffer and humidified air.

Recording and stimulation. Extracellular recordings were made with 2-10 M $\Omega$ glass microelectrodes made from borosilicate glass containing a capillary fiber $(0.6 \mathrm{~mm}$ inner diameter, $1.0 \mathrm{~mm}$ outer diameter; A \& M Systems, Everett, WA). Electrodes were pulled horizontally (Sutter Instruments, Novato, CA) and filled with $1 \mathrm{M} \mathrm{NaCl}$. Intracellular electrodes were filled with $1 \mathrm{M}$ potassium acetate and were 80-150 M $\Omega$. A dual channel intracellular amplifier with a bridge circuit (Axon Instruments, Burlingame, CA) was used for recording. Signals were monitored by oscilloscope (Nicolet Instruments, Madison, WI) and recorded on tape (Neurodata Instruments, New York, NY). Stimulation employed twisted metal bipolar electrodes (each pole $=50 \mu \mathrm{m}$ diameter) that were placed on the surface of the slice. The stimulation site in the fimbria was in the ventral portion of the white matter (see Fig. 3). The molecular layer stimulation site was usually in the upper blade, ventral to the border of area CA1 and the subiculum (see Fig. 3). For stimulation, rectangular current pulses (50-200 $\mu \mathrm{A}, 10-200 \mu \mathrm{sec}$ duration) were triggered at $0.1 \mathrm{~Hz}$. When recordings were made from the area $\mathrm{CA} 3$ pyramidal cell layer, the recording electrode was placed in one of three locations, either at the dorsal edge of the fimbria ("CA3a"), at the most ventral part of the CA3 pyramidal cell layer ("CA3b"; see Fig. 3), or in the center of that segment of the pyramidal cell layer that lies between the dorsal and ventral blades of the dentate gyrus ("CA3c"; see Fig. 13).

Electrophysiological differentiation of cell types and terminology. Three dentate cell types were distinguished in this study: granule cells, spiny hilar cells (including mossy cells), and relatively aspiny cells (i.e., interneurons). Although anatomical subcategorization is possible (Amaral, 1978; Ribak and Seress, 1983; Hu et al., 1993), the subcategories can not be distinguished electrophysiologically at this time.

Morphological and electrophysiological criteria used to distinguish the different cell populations have been described in detail elsewhere (Scharfman, 1992). In this study, only electrophysiological criteria were used. These criteria consisted of a combination of intrinsic and synaptic characteristics. For example, spike frequency adaptation is weak in aspiny cells, is variable in spiny cells, and strong in granule cells (Fricke and Prince, 1984; Scharfman and Schwartzkroin, 1988; Scharfman, 1992). The afterpotential following individual action potentials is large and hyperpolarizing in aspiny cells, usually depolarizing in spiny cells, and triphasic in granule cells (Fricke and Prince, 1984; Scharfman and Schwartzkroin, 1988; Scharfman, 1992). Spontaneous synaptic potentials are inhibitory in granule cells (Otis et al., 1991), and usually small or absent if sharp electrodes are used (Scharfman, 1992). Spiny hilar cells have very large, frequent spontaneous EPSPs (Scharfman and Schwartzkroin, 1988; Scharfman, 1993b). Spontaneous potentials of aspiny cells have fast kinetics (Livsey and Vicini, 1992) and are usually small in amplitude when recorded with sharp electrodes (Scharfman, 1992, 1993a).

Most spiny cells have morphological characteristics similar to mossy cells (Amaral, 1978; Ribak et al., 1985; Frotscher et al., 1991). Most aspiny cells are morphologically similar to interneurons (Ramón y Cajal, 1911; Amaral, 1978; Ribak and Seress, 1983; Hu et al., 1993). Therefore, the nomenclature used for these cell types is simplified in the text by referring to spiny cells as mossy cells and the relatively aspiny cells as interneurons.

Drug application. Drugs were stored in frozen aliquots of concentrated stock solution: bicuculline methiodide $(10 \mathrm{~mm}$ in $0.9 \% \mathrm{NaCl}$; Sigma, St. Louis, MO), 2-hydroxy-saclofen (10 mm in $10 \mathrm{~mm} \mathrm{NaOH}$; Tocris Neuramin, Bristol, UK), CNQX (10 mm in $10 \mathrm{~mm} \mathrm{NaOH}$; Tocris Neuramin), D-APV ( $10 \mathrm{~mm}$ in $0.9 \% \mathrm{NaCl}$; Sigma), atropine methylbromide (10 $\mathrm{mm}$ in $0.9 \% \mathrm{NaCl}$; Sigma), mecamylamine $(10 \mathrm{~mm}$ in $0.9 \% \mathrm{NaCl}$; 


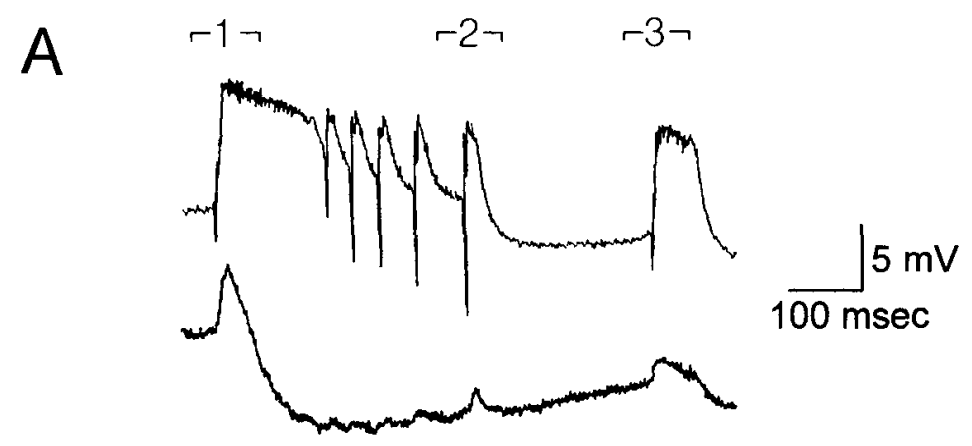

Figure 1. In the presence of bicuculline, epileptiform bursts occur in area CA3 and EPSP-IPSP sequences occur in granule cells. $A$, Simultaneously recorded spontaneous activity in the area CA3b pyramidal cell layer and a dentate granule cell is shown. Recordings were made in the presence of $25 \mu \mathrm{M}$ bicuculline. Top, An epileptiform burst in area CA3b that occurred spontaneously. Bottom, Simultaneous to the burst in area CA3b, an EPSP-IPSP sequence occurred in the granule cell. Granule cell membrane potential $=-65 \mathrm{mV}$; resting potential $=-72 \mathrm{mV} . B$, The parts of the traces in $A$ labeled by numbers are shown with an expanded time base. 1 , The onset of the epileptiform burst shows that the first population spike of the area CA3 burst preceded the onset of the granule cell EPSP. 2 and 3 , The afterdischarges of the pyramidal cells preceded small, secondary EPSPs in the granule cell.

Sigma), pirenzipine hydrochloride ( $10 \mathrm{~mm}$ in $0.9 \% \mathrm{NaCl}$; Research Biochemicals Inc., Natick, MA), and dihydro- $\beta$-erythroidine $(10 \mathrm{~mm}$ in $0.9 \% \mathrm{NaCl}$; Merck Sharp and Dohme, Rahway, NJ). For bath application, an aliquot of stock solution was added to an appropriate volume of buffer immcdiately beforc use to yicld the desircd final concentration. To demonstrate reversibility, perfusion was switched from the buffer containing drug to drug-free buffer. For focal application, a low-resistance (10-20 M $\Omega$ ) glass pipette was filled with either $25 \mu \mathrm{M}$ CNQX or $100 \mu \mathrm{M}$ D-APV. Drug was ejected by a pulse of pressure $(20-250 \mathrm{msec}$, $10-20 \mathrm{lb} /$ square inch) using a Picospritzer (General Valve Corp., Fairfield, NJ), so that a 1-sec-duration pulse produced a droplet at the end of the pipette that was approximately $50 \mu \mathrm{m}$ in diameter when the pipette was in the air. Droplet diameter was measured with an ocular micrometer. A $50 \mathrm{msec}$ pulse produced a droplet that was rarely detectable in air. The pipette was placed on the slice surface at the desired location and slowly advanced $50 \mu \mathrm{m}$. Ejection was triggered after ensuring that placement of the pressure pipette did not alter the physiological properties or synaptic responses of the impaled cell. After use, pressure pipettes were raised in the air to ensure that the 1-sec-duration pulse still produced a droplet that was approximately $50 \mu \mathrm{m}$ in diameter.

Data analysis. Input resistance was defined as the maximum slope of the $V-I$ plot of steady state responses to a family of hyperpolarizing, $150 \mathrm{msec}$ current pulses injected intracellularly. Time constant was estimated as the time to reach $63 \%$ of the steady state amplitude of a voltage response to a $0.05-0.1 \mathrm{nA}, 150 \mathrm{msec}$ hyperpolarizing current pulse. The half-duration of EPSPs was defined as the time from the EPSP onset to the point where EPSP amplitude had decreased to half of its peak amplitude. Statistical tests were performed using PSI-PLOT software (Polysoftware International, Salt Lake City, UT). Statistical significance was set at $p<0.05$ prior to all experiments.

\section{Results}

This study was based on 78 experiments in which bicuculline was bath applied. In all slices, area CA3 pyramidal cells began to burst spontaneously 6-11 min after 10-25 $\mu \mathrm{M}$ bicuculline was added to the perfusate. These bursts were composed of multiple population spikes if recorded extracellularly, and depolarization shifts if examined intracellularly, as has been described in studies using $\mathrm{GABA}_{\mathrm{A}}$ receptor antagonists (Dichter and Spencer, 1969; Schwartzkroin and Prince, 1977; Dingledine and Gjer- stad, 1980; Wong and Traub, 1983; Hablitz, 1984; Swann et al., 1986). When granule cells were impalcd in thesc slices, spontaneous depolarizations occurred within milliseconds of the onset of each epileptiform burst of pyramidal cells $(n=48$ paired recordings; Fig. 1). Granule cell depolarizations occurred during the epileptiform bursts of hilar mossy cells also $(n=77$; Fig. 2 ), which is consistent with the finding that, upon exposure to bicuculline, synchronized depolarization shifts occur in pyramidal cells and mossy cells (Scharfman, 1994b). Epileptiform bursts of pyramidal cells and depolarizations of granule cells were evoked by stimulation of many areas of the slice, including the fimbria, dendritic layers of area $\mathrm{CA} 1, \mathrm{CA} 2$, or $\mathrm{CA} 3$, the molecular layer of the dentate gyrus, or the hilus (Fig. 3).

Both the area CA3 bursts and granule cell depolarizations were all or none events that had a similar threshold; the minimal stimulus that was sufficient to evoke a pyramidal cell burst also evoked a granule cell depolarization, and both the burst and depolarization maintained a similar amplitude and duration despite further increases in stimulus strength (Fig. 4). However, if two stimuli were triggered with less than a 2 sec interstimulus interval, the second stimulus often produced an abbreviated pyramidal cell burst and a reduced granule cell EPSP (Fig. 4). It has been previously shown that pyramidal cell bursts and mossy cell bursts are similar, are all or none, and share a similar threshold (Scharfman, 1994b). Thus, excitatory events of pyramidal cells, mossy cells and granule cells required similar stimulus parameters, and behaved similarly in response to changes in stimulus frequency.

Granule cell depolarizations were followed by large hyperpolarizations (Figs. 1, 2). Large hyperpolarizations have been previously described in guinea pig hippocampal slices perfused with picrotoxin and 4-aminopyridine; they appear to be mediated by $\mathrm{GABA}_{\mathrm{B}}$ receptors coupled to potassium channels (Müller and Misgeld, 1991). The granule cell hyperpolarizations recorded in this study also appeared to be mediated by $\mathrm{GABA}_{\mathrm{B}}$ receptors, hecause they were blocked reversibly by addition of 

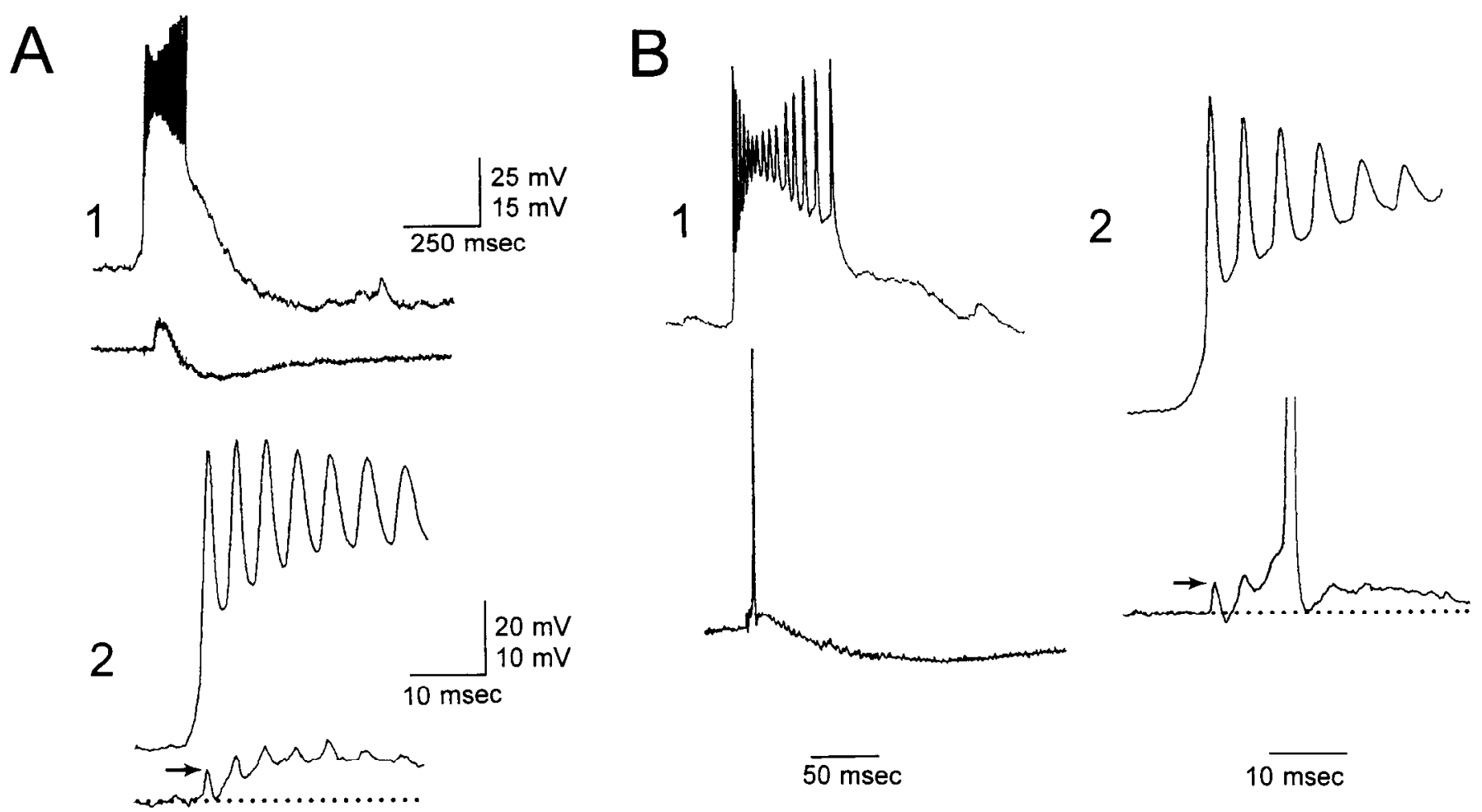

Figure 2. In the presence of bicuculline, epileptiform bursts of hilar "mossy" cells occur simultaneous to EPSP-IPSP sequences of granule cells. $A 1$, Simultaneous intracellular recording of spontaneous activity of a mossy cell (top) and a granule cell (bottom) are shown in the presence of bicuculline $(25 \mu \mathrm{M})$. The mossy cell was at its resting potential $(-70 \mathrm{mV})$. Granule cell membrane potential $=-62 \mathrm{mV}$; resting potential $=-72$ $\mathrm{mV}$. Calibration: for mossy cell, $25 \mathrm{mV}$; for granule cell, $15 \mathrm{mV}$. $A 2$, The onsets of the spontaneous events in $A 1$ are shown with an expanded time base. The onset of the granule cell EPSP occurred immediately after the capacitative artifact of the mossy cell's first action potential. The first capacitative artifact is marked with an arrow. Calibration: for mossy cell, $20 \mathrm{mV}$; for granule cell, $10 \mathrm{mV}$. $B$, Simultaneous intracellular recording from a different mossy cell (top) and a different granule cell (bottom) are shown. BI, A spontaneous depolarization shift of the mossy cell and the granule cell EPSP-IPSP are shown. One action potential was triggered in the granule cell during its EPSP. The mossy cell was at its resting potential $(-66 \mathrm{mV})$. Granule cell membrane potential $=-62 \mathrm{mV}$; resting potential $=-80 \mathrm{mV}$. Voltage calibration is the same as for $A 1$. B2, The onset of the activity in $B I$ is shown with an expanded time base. The first action potential of the mossy cell produced the capacitative artifact that is marked by an arrow. The granule cell action potential is clipped. Voltage calibration is the same as for $A 2$.

saclofen to the buffer (250-500 $\mu \mathrm{M}, n=27$; data not shown). In other experiments, whenever saclofen was present the hyperpolarizations were absent (Figs. $3,4,7,9 A, B, 10,12,13$ ), and whenever saclofen was not present the hyperpolarizations occurred (Figs. 1, 2, 5, 9C).

\section{Characterizations of spontaneous and fimbria-evoked} EPSPs of granule cells

If a granule cell was depolarized with intracellular current injection, action potentials could be triggered on the depolarization that occurred during the pyramidal cell bursts (Fig. 2; see also Figs. 7, 9, 13). Therefore, the depolarization appeared to be an EPSP. To study these EPSPs further, both spontaneous and evoked EPSPs were examined. Fimbria stimulation was used to evoke EPSPs because a previous study showed that the fimbria could be stimulated without activation of the perforant path or antidromic activation of granule cells (Scharfman, 1993a).

Spontaneous and fimbria-evoked EPSPs of granule cells were similar (Figs. 3, 5). The mean amplitude of spontaneous EPSPs near resting potential $(-75$ to $-80 \mathrm{mV})$ was $6.5 \pm 1.0 \mathrm{mV}$ (mean $\pm \mathrm{SEM}, n=21$ ) and the mean amplitude of fimbriaevoked EPSPs of the same cells was $6.2 \pm 1.3 \mathrm{mV}$. The mean half-duration of spontaneous EPSPs at resting potential was 56 $\pm 8 \mathrm{msec}(n=21)$, and for fimbria-evoked EPSPs the mean half-duration was $63 \pm 10 \mathrm{msec}$. These amplitudes and half- durations were not statistically different (paired $t$ tests, $p>0.05$ ). Spontaneous or evoked EPSPs did not trigger action potentials at resting potential, but if a cell was depolarized to potentials positive to $-50 \mathrm{mV}$, one to four action potentials were triggered in 26 of 28 cells. The mean maximum number of action potentials per cell for fimbria-evoked EPSPs was $1.5 \pm 0.2$. In the two exceptional cells, EPSPs did not trigger action potentials even when cells were depolarized to the level of spontaneous discharge ( -40 to $-50 \mathrm{mV})$.

Spontaneous and fimbria-evoked EPSPs were maximal within a window of membrane potentials between approximately -50 and $-60 \mathrm{mV}$ (Fig. 5). For 21 cells in which fimbria-evoked EPSPs were examined at 3-5 $\mathrm{mV}$ intervals between approximately -40 and $-100 \mathrm{mV}$, the maximal EPSPs amplitude was $9.5 \pm 1.0 \mathrm{mV}$, and the membrane potential where the maximal EPSP was recorded was $-61 \pm 3.2 \mathrm{mV}$. When granule cells were hyperpolarized from $-60 \mathrm{mV}$, EPSP amplitude decreased in 12 cells and did not change in seven; in the remaining two cells, EPSP amplitude first increased and then decreased. The mean decrease in EPSP amplitude was $3.6 \pm 0.5 \mathrm{mV}$, or 45.7 $\pm 6.0 \%(n=12)$. EPSP half-duration decreased in 14 cells (mean $40 \pm 7 \mathrm{msec}$ or $43.3 \pm 4.1 \%, n=14$ cells) or did not change. EPSP amplitude and duration were measured only when both bicuculline and saclofen were present.

One possible explanation for the lack of change or decrease 


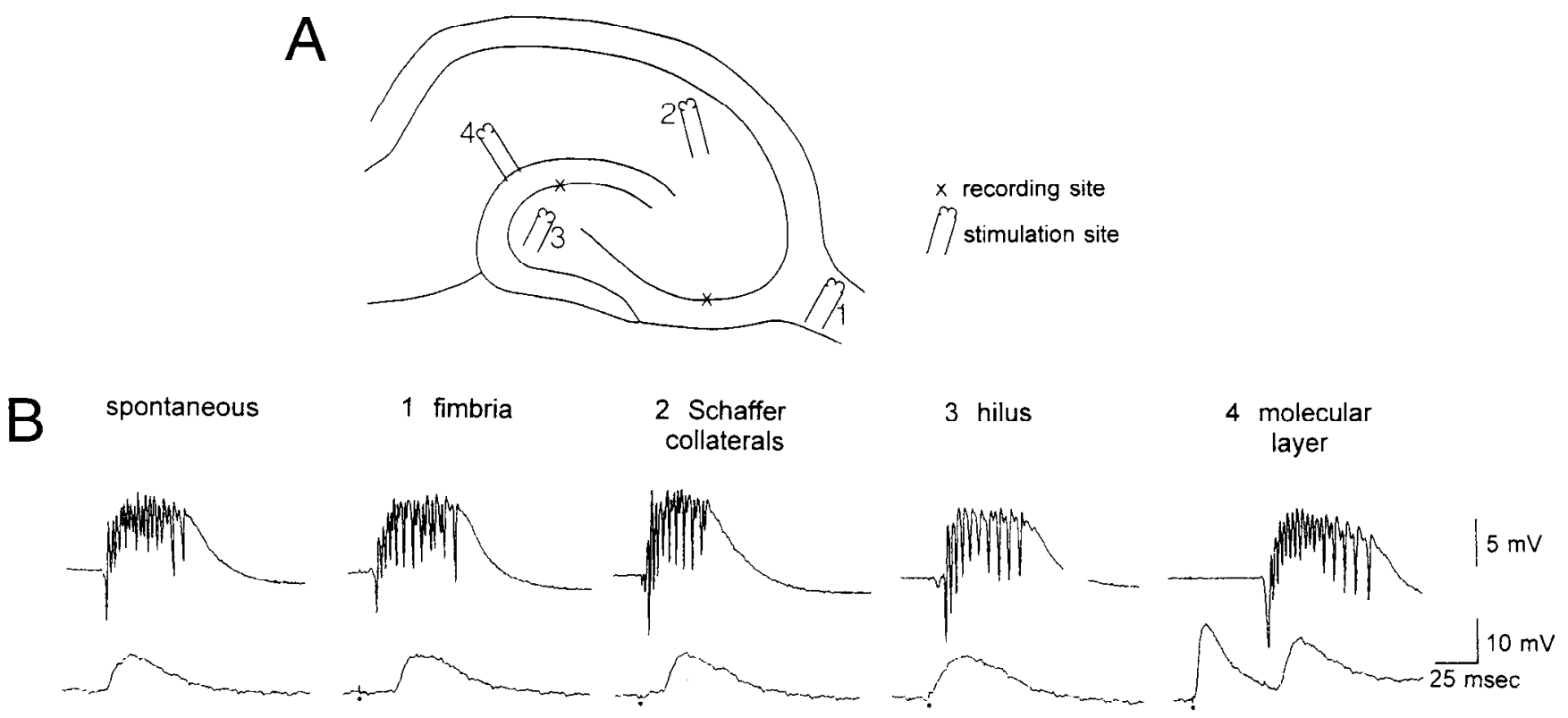

Figure 3. Similarity of pyramidal cell bursts and granule cell EPSPs evoked by different stimulus sites. $A$, A schematic illustrates the positions of stimulating electrodes (numbered $1-4$ ), and recording electrodes, (marked by $\times$ ), used to evoke the potentials shown in $B$. One recording electrode was located in the area CA3b pyramidal cell layer to record pyramidal cell epileptiform bursts extracellularly. The second recording electrode was used to record from a granule cell intracellularly. The stimulation sites were the fimbria (1), the Schaffer collateral axons (2), the hilus (3), and the outer molecular layer (4). Both $25 \mu \mathrm{M}$ bicuculline and $250 \mu \mathrm{M}$ saclofen were present in the buffer. $B$, Simultaneous recordings from the area CA3b pyramidal cell layer (top) and a granule cell (bottom). On the far left is a recording of a spontaneous epileptiform burst of area CA3 simultaneous to a spontaneous EPSP in the granule cell. 1-4, Stimuli to different sites in the slice produced similar burst discharges in area CA3b and similar granule cell EPSPs. Stimuli are marked by dots. Granule cell membrane potential $=-70 \mathrm{mV}$; resting potential $=-75 \mathrm{mV}$.

in the EPSP with hyperpolarization is that granule cell membrane properties changed with hyperpolarization. Indeed, the membrane properties of granule cells did appear to change with hyperpolarization (Fig. 6), as has been noted previously (Lambert and Jones, 1990). For 10 granule cells that were examined between approximately -40 and $-100 \mathrm{mV}$, input resistance decreased from $97.5 \pm 5.4 \mathrm{M} \Omega$ to $40.1 \pm 2.5 \mathrm{M} \Omega$ and time constant decreased from $15.5 \pm 1.0 \mathrm{msec}$ to $5.1 \pm 1.4 \mathrm{msec}$ (Fig. 6). Therefore, changes in intrinsic properties could have been at least partly responsible for the decrease in EPSPs with hyperpolarization. Consistent with that hypothesis, EPSPs evoked by another afferent input, the perforant path, also decreased in amplitude with hyperpolarization (Fig. 7A). Specifically, EPSPs evoked by molecular layer stimulation decreased in amplitude ( 7 of 10 cells) or did not change ( 3 of 10 cells) when cells were hyperpolarized (Fig. $7 A$ ). The half-duration of EPSPs evoked by molecular layer stimulation decreased in all cells (Fig. 7A). However, only EPSPs evoked by weak molecular layer stimulation behaved in this way (i.e., EPSPs that were evoked by low stimulus strengths so that they were similar in amplitude to fimbria-evoked EPSPs; compare Fig. $7 A, B$ ). When stimulation of the molecular layer was stronger, molecular layerevoked EPSPs increased in amplitude with hyperpolarization (Fig. $7 B$ ). The increase in amplitude was not quantified because action potential discharge obscured the peaks of these EPSPs at many membrane potentials (Fig. $7 B$ ). Duration was not quantified because of the difficulty in separating the afterhyperpolarization following action potentials from the EPSP. The difference in behavior of EPSPs produced by weak and strong stimuli in response to changes in membrane potential could be due to greater or lesser synaptic currents relative to the con- ductances activated by membrane potential changes. That is, stronger synaptic currents may override the influence of hyperpolarization-activated conductance increases, or conductance decreases due to depolarization. A different explanation stems from the evidence that both AMPA/kainate and NMDA receptors participate in EPSPs evoked by perforant path stimulation (Collingridge et al., 1984; Dahl et al., 1990; Lambert and Jones, 1990; Keller et al., 1991). If NMDA receptors participate more than AMPA/kainate receptors in EPSPs produced by low stimulus strengths, such EPSPs would be expected to decrease in amplitude with hyperpolarization more than EPSPs produced by high stimulus strengths.

In summary, EPSPs evoked by weak stimulation of the molecular layer were similar to fimbria-evoked EPSPs in their responses to changes in membrane potential. They also were similar in that they triggered similar numbers of action potentials, if depolarized (Fig. 7A). However, EPSPs evoked by strong stimulation of the molecular layer differed from fimbria-evoked EPSPs in their variation with membrane potential, as well as in other respects. For example, strong stimulation of the molecular layer could produce EPSPs that were over twice the amplitude of spontaneous or fimbria-evoked EPSPs (Fig. 7). In addition, EPSPs evoked by strong stimuli could evoke extensive action potential discharge, and discharge could occur from resting potential (Fig. 7).

Relative timing of pyramidal cell, mossy cell, granule cell, and interneuron excitation

Simultaneous recordings were used to determine the relative timing of activity among the four different cell types: pyramidal cell, granule cells, mossy cells, and dentate interneurons. 

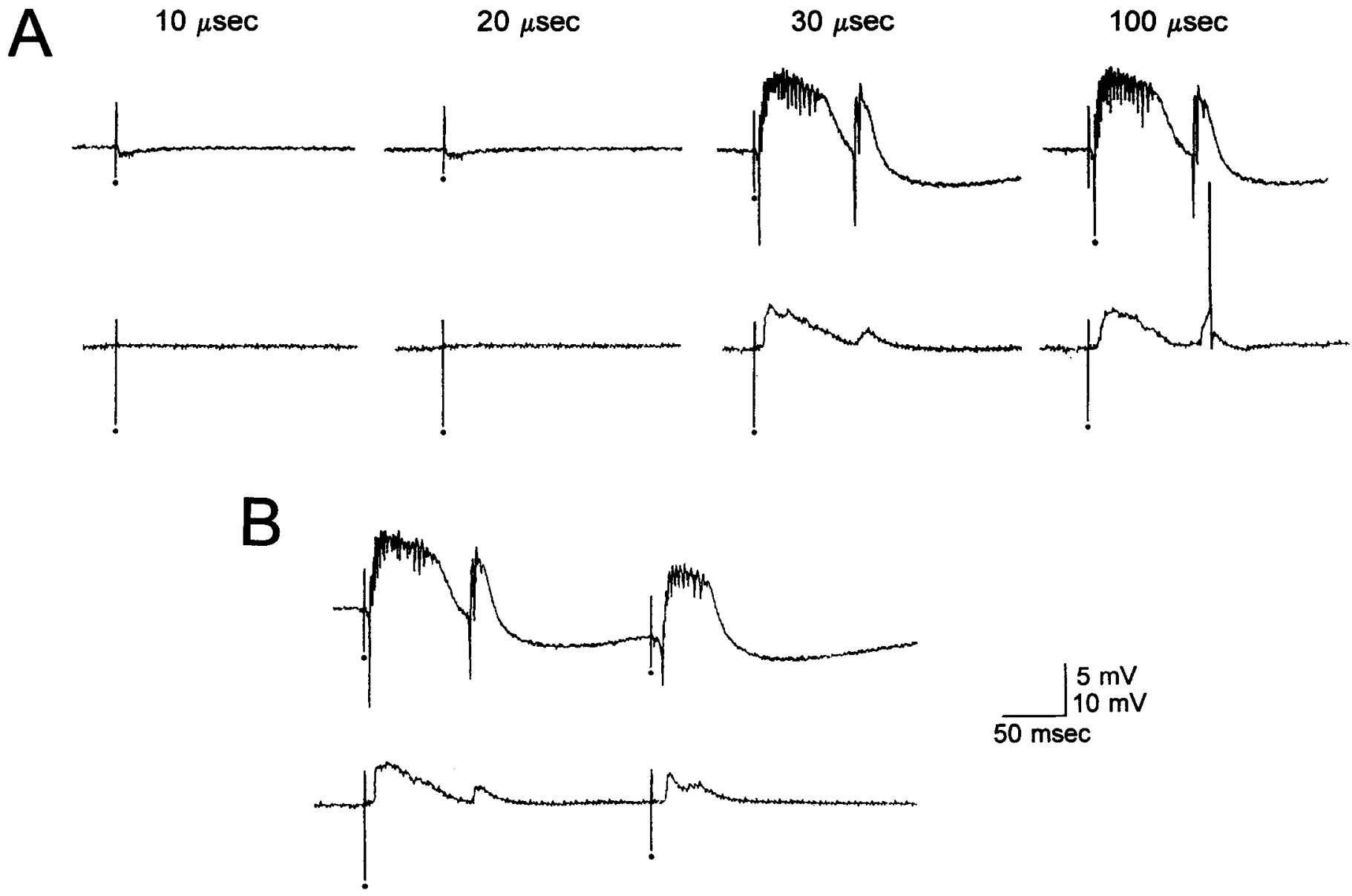

\section{$\mid \begin{aligned} & 5 \mathrm{mV} \\ & 10 \mathrm{mV}\end{aligned}$ \\ $50 \mathrm{msec}$}

Figure 4. Similarity in stimulus parametcrs uscd to cvokc pyramidal ccll bursts and granulc cell EPSPs. Simultaneous extracellular recordings from the area CA3c pyramidal cell layer $(t o p)$ and intracellular recordings from a granule cell (bottom) are shown in the presence of bicuculline (25 $\mu \mathrm{M})$ and saclofen $(250 \mu \mathrm{M}) . A$, Fimbria stimulation at low intensities $(10,20 \mu \mathrm{sec})$ evoked little or no activity in pyramidal cells recorded extracellularly or the granule cell that was sampled intracellularly. However, an epileptiform burst and EPSP were evoked when stimulus strength was raised to $30 \mu \mathrm{sec}$. A similar burst and similar EPSP occurred when stimulus strength was raised to $100 \mu \mathrm{sec}$. Stimulus frequency $=0.1 \mathrm{~Hz}$. Stimulation occurred at the dots. The granule cell action potential is clipped. Granule cell membrane potential $=-68 \mathrm{mV}$; resting potential $=-78 \mathrm{mV}$. Calibration: for extracellular records (in $B$ ), $5 \mathrm{mV}$; for intracellular records, $10 \mathrm{mV}$. $B$, Responses to two successive fimbria stimuli are shown for the same recording sites as in $A$. Two identical $30 \mu \mathrm{sec}$ stimuli were delivered with a short interstimulus interval. The response to the second stimulus produced a smaller burst and a smaller EPSP.

\section{Pyramidal cells and granule cells}

To examine the timing of pyramidal cell bursts relative to granule cell EPSPs, the time was measured between the peak of the first population spike of the pyramidal cell epileptiform burst and the onset of the simultaneously recorded granule cell EPSP. It was assumed that the peak of the first population spike represented the time when most cells in the local area generated the first action potential of their paroxysmal depolarization shift (PDS). Four spontaneous and four fimbria-evoked bursts were sampled for each paired recording.

In all fimbria-evoked bursts, pyramidal cell bursts began before granule cell EPSPs ( $n=48$ paired recordings). The mean interval between bursts and EPSPs was $6.9 \pm 0.5 \mathrm{msec}(n=$ 46). For recordings only from area CA3a, the mean interval was $8.7 \pm 0.9 \mathrm{msec}(n=13)$; for area CA3b, $7.5 \pm 0.6 \mathrm{msec}(n=$ 19); and for area CA3c, $4.3 \pm 0.8(n=16)$. Both the area CA3a interval and the area CA3b interval were significantly different from area CA3c (Student's $t$ test, $p<0.05$ ). However, the mean interval of area CA3a was not different from that of area CA3b (Student's $t$ test, $p>0.05$ ). These data indicated that fimbria- evoked bursts first occurred in pyramidal cells and specifically in area $\mathrm{CA} 3 \mathrm{a}$ or $\mathrm{CA} 3 \mathrm{~b}$.

There was considerable variability when spontaneous bursts were examined. Although in almost every case the pyramidal cell population spike peak occurred before the granule cell EPSP began (Fig. 1), the intervals varied by as much as $10 \mathrm{msec}$ from one burst to the next (bursts were 5-10 sec apart). There were no significant differences among the mean intervals of spontaneous bursts for areas CA3a $(6.0 \pm 1.8, n=13), \mathrm{CA} 3 \mathrm{~b}(4.4 \pm$ $0.7, n=19)$, and CA3c (3.8 $\pm 0.7, n=16$; ANOVA, $p>0.05)$. There were three exceptional cases in which the granule cell EPSP preceded the first population spike of the pyramidal cell burst, although this only occurred in one or two of the four spontaneous bursts that were sampled. When it did occur, the interval between the EPSP onset and the peak of the first population spike was brief $(<3 \mathrm{msec})$. In the experiments where this was observed, additional recordings were made in area CA3 to determine if the granule cell EPSP preceded the bursts of other pyramidal cell populations. In each case the bursts of other subfields preceded granule cell EPSPs, and did so substantially $(6-12 \mathrm{msec})$. Therefore, although some granule cells appeared 
A

CONTROL

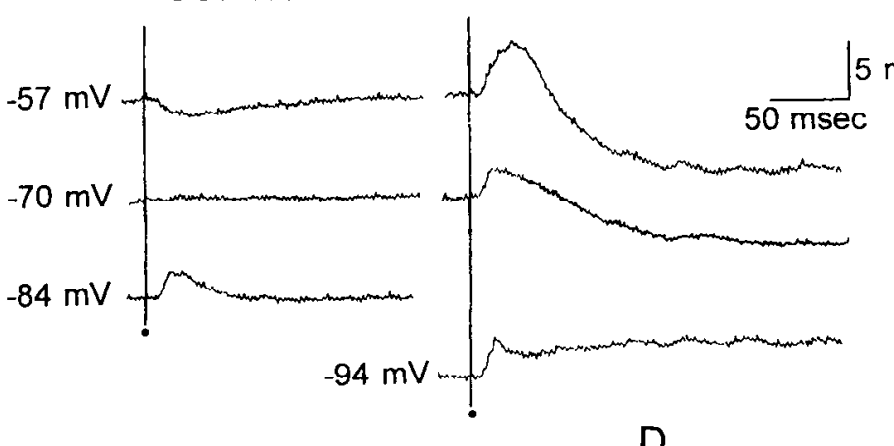

BICUCULLINE

spontaneous
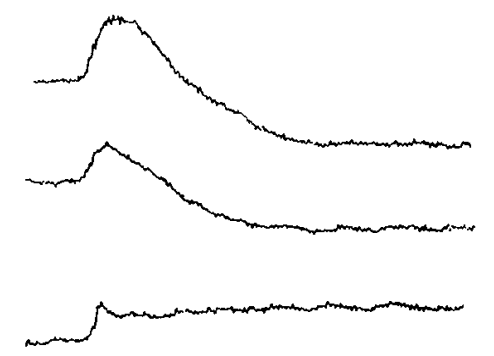

C WASH

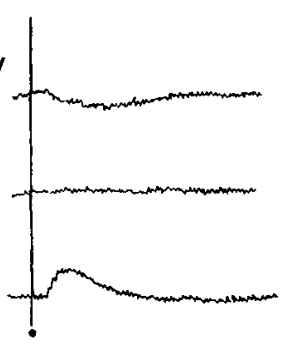

Figure 5. Fimbria-evoked responses of a granule cell before and after bicuculline bath application and their change with membrane potential. $A$, In control conditions, stimulation of the fimbria evoked a small IPSP in a granule cell. The IPSP is shown at three different membrane potentials. Stimulus artifacts are marked by dots. $B$, Responses to the same stimulus are shown following bath application of $10 \mu \mathrm{M}$ bicuculline. The top trace was recorded at -57 $\mathrm{mV}$; the center trace, at $-70 \mathrm{mV}$; and the lower trace, at $-94 \mathrm{mV}$. C, Following perfusion with drug-free buffer, the responses to stimulation were similar to control. Responses in $C$ were evoked at the same membrane potentials as in $A$. $D$, At the time in the experiment that the responses in $B$ were recorded, spontaneous EPSP-IPSP sequences were also recorded. The three traces shown are three examples of such spontaneous events, recorded at the same membrane potentials as the croked responses shown in $B$. That is, the top trace was evoked at $-57 \mathrm{mV}$; the middle trace, at $-70 \mathrm{mV}$; and the botlom trace, at $-94 \mathrm{mV}$. Granule cell resting potential $=-82 \mathrm{mV}$.

to be excited prior to some area CA 3 cells, there was no occasion when a granule cell EPSP began before the burst of every CA3 population that was sampled in the slice.

These data indicate that spontaneous bursts originate in area CA3, like fimbria-evoked bursts. However, spontaneous bursts may originate in any of the three subfields, whereas fimbriaevoked bursts originate only in subfields CA3a or CA3b. In addition, the data suggest that excitatory activity can propagate as fast to the dentate as to adjacent CA3 subfields.

\section{Mossy cells, granule cells, and interneurons}

Mossy cells and granule cells. To determine the relative timing of granule cell EPSPs and mossy cell depolarization shifts, 32 mossy cells were recorded simultaneous to different granule cells $(n=77)$. The onset of the granule cell EPSP began immediately after the capacitative artifact of the first action potential of the mossy cell epileptiform burst in all paired recordings $(n=77$; Fig. 2). Unlike the case for pyramidal cells, there was little variability from one burst to the next in the relative timing of mossy cell depolarization shifts and granule cell EPSPs.

Mossy cells and interneurons. Nine mossy cells were recorded simultaneous to nine different interneurons. The interval was measured between the peak of the first action potential of the mossy cell and the onset of the interneuron depolarization. In seven cases, the interneuron depolarization began immediately after the first action potential of the simultaneously recorded mossy cell (Fig. 8). In this respect, the interneurons were similar to granule cells. However, in the remaining two cases, the onset
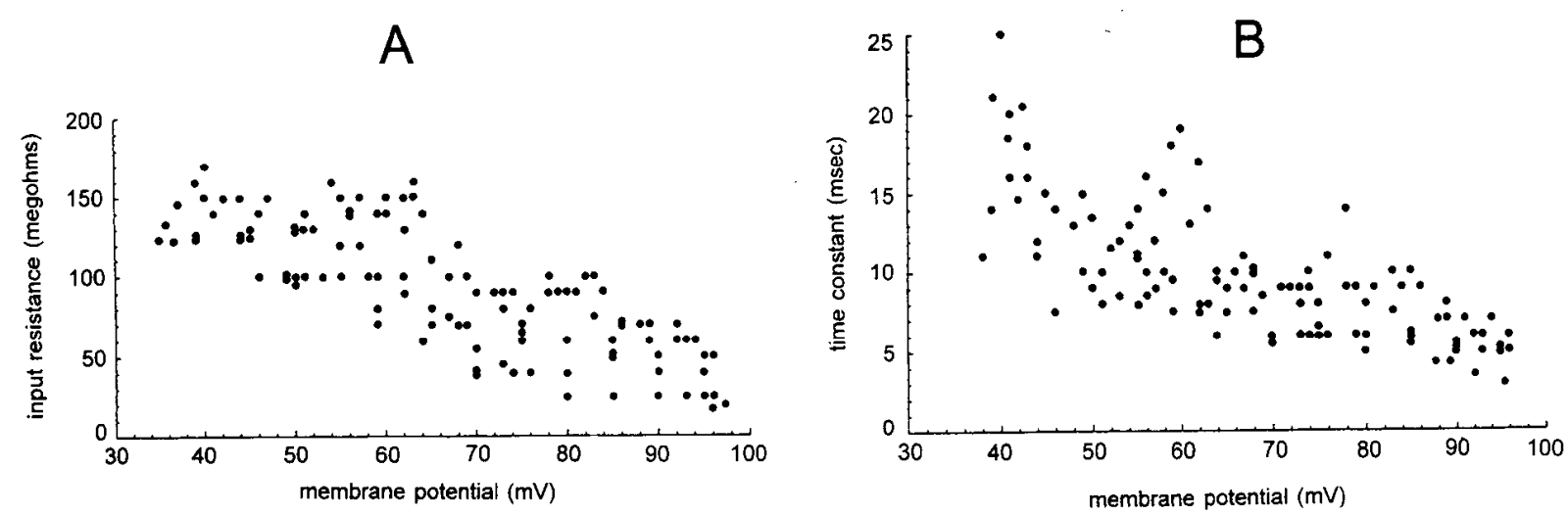

Figure 6. Effect of membrane potential on input resistance and time constant of dentate granule cells. A plot of input resistance $(A)$ and time constant $(B)$ as a function of membrane potential are shown for 10 granule cells sampled from 10 different slices. Input resistance was estimated from the response to a $-0.1 \mathrm{nA}, 150 \mathrm{msec}$ hyperpolarizing current pulse elicited from various membrane potentials between $-35 \mathrm{mV}$ and -100 $\mathrm{mV}$. Time constants were estimated from the response to a $-0.1 \mathrm{nA}, 150 \mathrm{msec}$ pulse from each membrane potential. 
Figure 7. Responses to low- and highintensity molecular layer stimulation in the presence of bicuculline $(25 \mu \mathrm{M})$ and saclofen $(500 \mu \mathrm{M}) . A$, Responses of a granule cell are shown to low-intensity stimulation of the molecular layer $(60$ $\mu \mathrm{A}, 20 \mu \mathrm{scc})$. This stimulus cvoked a short-latency EPSP, presumably due to activation of perforant path fibers. The same stimulus also evoked a burst in area $\mathrm{CA} 3 \mathrm{a}$ at a longer latency (top trace). During the CA3 burst, a second EPSP occurred in the granule cell (arrows). As the cell was hyperpolarized both the short- and long-latency EPSPs decreased in amplitude and duration. Note that at this low stimulus strength the latency to the CA3 burst varied from stimulus to stimulus, and the latency of the associated granule cell EPSP changed similarly. The extracellular trace shown was recorded simultaneous to the granule cell response at $-48 \mathrm{mV}$. Stimuli are marked by dots. Calibration: for extracellular records, $5 \mathrm{mV}$; for intracellular records, $15 \mathrm{mV} . B$, The responses of the same granule cell as in $A$ to higher intensity stimulation of the molecular layer are shown $(60 \mu \mathrm{A}, 100 \mu \mathrm{sec})$. Note that the underlying EPSP appears to increase in amplitude as the cell is hyperpolarized, in contrast to the EPSPs evoked by weak stimulation in $A$. The large population spikes evoked in granule cells by high-intensity stimulation can be seen in some of the intracellular records (arrow). Granule cell resting potential $=-82 \mathrm{mV}$.
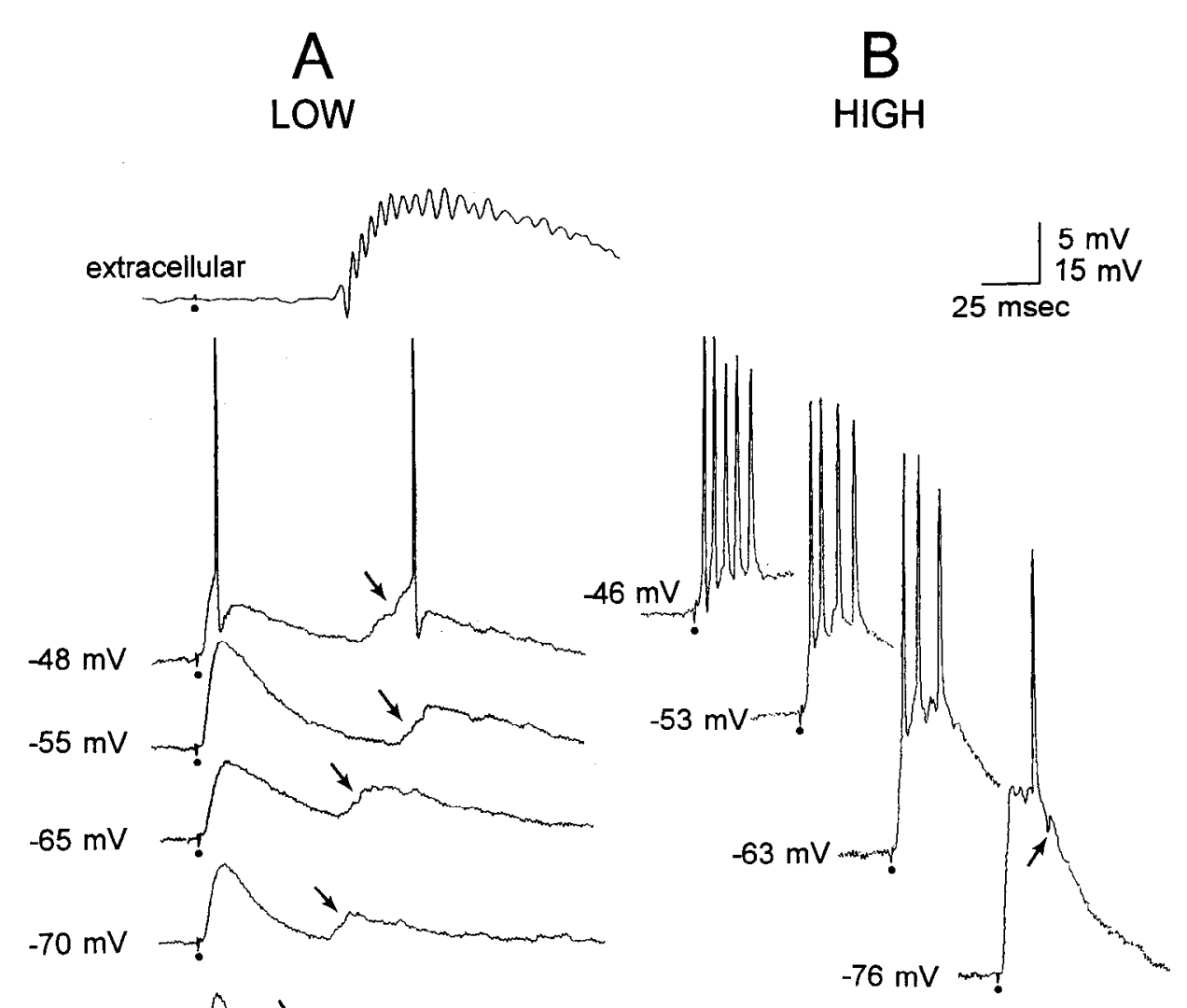

$-81 \mathrm{mV}$

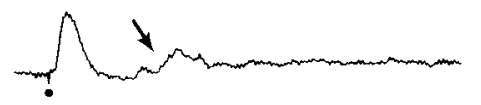

of interneuron excitation was variable relative to the onset of the mossy cell PDS, occurring either before the mossy cell burst onset, at the same time, or as much as $6 \mathrm{msec}$ later.

\section{Activity of granule cells during pyramidal cell afterdischarges}

In 40 of $78(51.3 \%)$ of experiments in which bicuculline was applied, area CA3 epileptiform bursts included afterdischarges. Such afterdischarges have been described previously and consist of relative small, brief positive waves accompanied by two to seven population spikes (Swann et al., 1986; Figs. 1, 4, 9, 11). The mean number of afterdischarges was $1.6 \pm 0.7(n=40)$. Granule cells depolarized during most afterdischarges (Figs. 1, $4,9)$. The depolarizations were probably EPSPs because they could trigger action potentials when the granule cell was depolarized (Figs. 4, 9). The EPSPs that occurred during afterdischarges were usually smaller than the EPSPs that occurred during the onset of the pyramidal burst (Figs. 1,4). In experiments where saclofen was not present, the smaller EPSPs could in part be due to shunting by the large $\mathrm{GABA}_{\mathrm{B}}$ receptor-mediated IPSP (e.g., Fig. 1). In other cases if may be due to the decreased discharge of pyramidal cells during afterdischarges relative to PDSs (e.g., Fig. 4).

The timing of pyramidal cell afterdischarges relative to the secondary EPSPs of granule cells was inconsistent. For the first afterdischarge the secondary EPSP was most consistent, almost always starting just after the peak of the first population spike (range $=1-8 \mathrm{msec}$; Fig. 4). In the exceptional cells, a secondary EPSP occurred before the afterdischarge began (Fig. 9A).
Later afterdischarges were not well synchronized with the EPSPs of granule cells (Fig. 9). Many secondary EPSPs actually appeared to peak before afterdischarges (Fig. 9). This observation, coupled to the fact that granule cells innervate pyramidal cells, raises the possibility that granule cells could have contributed to the initiation of afterdischarges. However, synaptic interactions with the dentate cannot be the sole mechanism underlying afterdischarges, because when area CA3 is severed from the dentate gyrus afterdischarges are not blocked (Swann et al., 1993).

Pharmacological analysis of granule cell EPSPs and epileptiform bursts of mossy cells and pyramidal cells

\section{AMPA/kainate receptor antagonists}

In five slices, a granule cell was impaled in the presence of bicuculline and its spontaneous and fimbria-evoked EPSP, as well as the extracellularly recorded burst in area CA3, were monitored during bath application of $5 \mu \mathrm{M}$ CNQX. In every case the EPSPs and the bursts were blocked (Fig. 10). The effects of CNQX occurred at the same time in granule cells and pyramidal cells; at the point when stimulation produced a smaller pyramidal cell epileptiform burst, the granule cell EPSP was also smaller (Fig. 10). At the point when stimulation failed to produce a pyramidal cell burst, it also failed to produce a granule cell EPSP (Fig. 10).

The effects of CNQX were reversible in the two slices where it was tested (Fig. 10). In the other slices, CNQX bath application was continued and 10 other granule cells were sampled. These cells had no spontaneous EPSPs and no response to fim- 


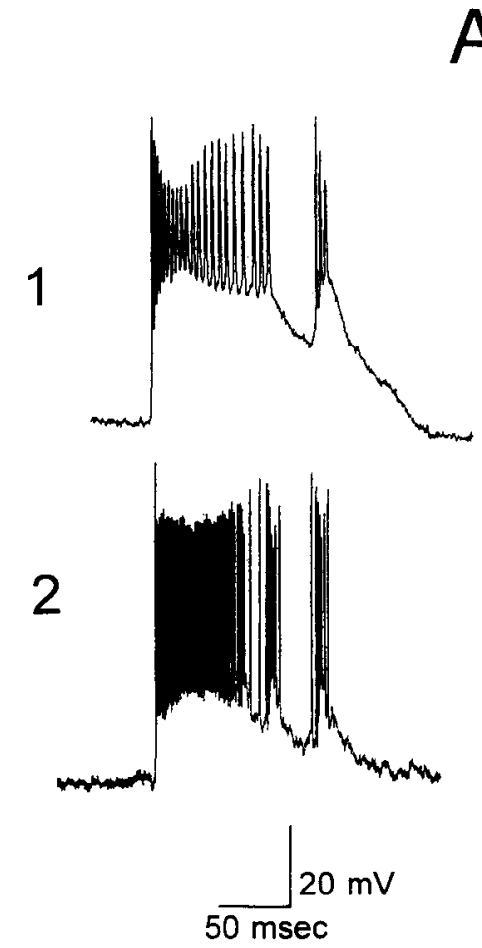

A

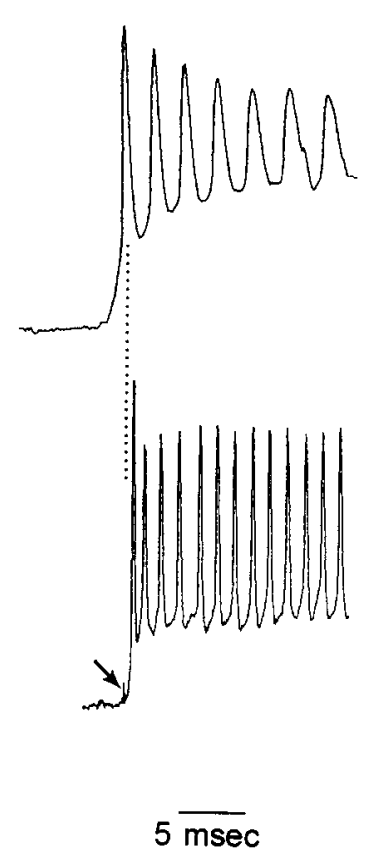

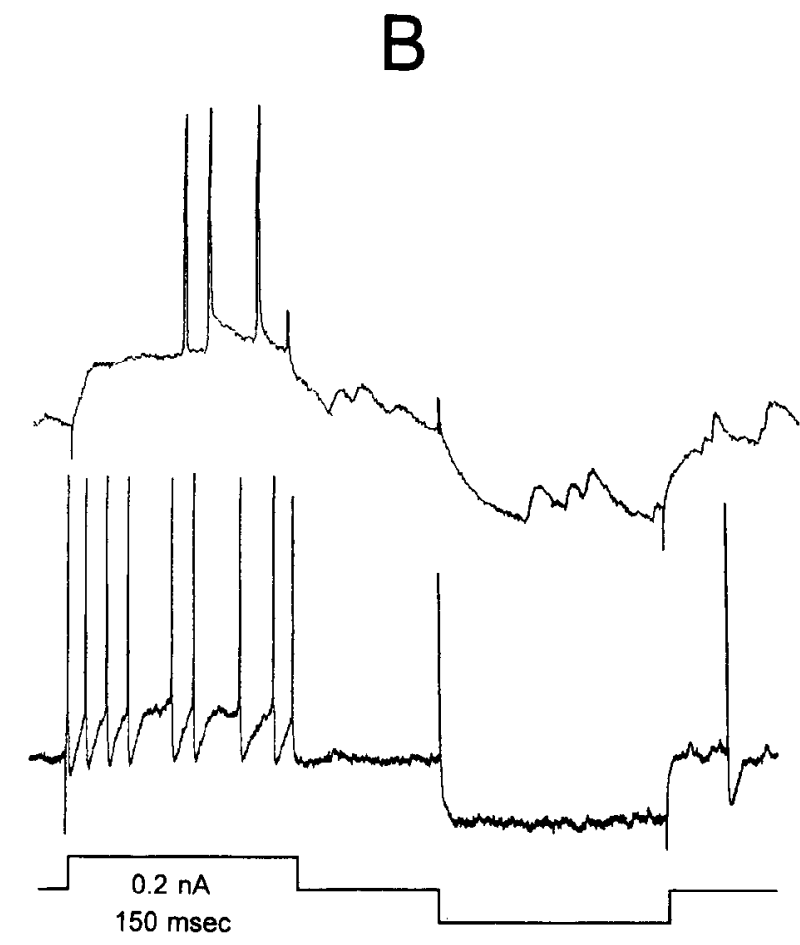

Figure 8. Spontaneous depolarization shifts in mossy cells occur before depolarization shifts of dentate interneurons. $A$, Simultaneous recordings are shown from a mossy cell ( 1 ) and a hilar interneuron (2) with two different time bases. At right the onset of the depolarization shift is shown with an expanded time base to illustrate that the first action potential of the mossy cell preceded the start of the depolarization shift of the interneuron. The arrow points to the capacitative artifact of the mossy cell's first action potential. Both the mossy cell and the interneuron were at their resting potentials (mossy cell, $-72 \mathrm{mV}$; interneuron, $-60 \mathrm{mV}$ ). B, Responses of the two cells in $A$ to depolarizing and hyperpolarizing current injection $( \pm 0.2 \mathrm{nA}, 150 \mathrm{msec}$ pulses) are shown (top, mossy cell; bottom, interneuron). Note the differences in spontaneous activity and responses to intracellular current injection. Detailed description of electrophysiological differentiation of these cell types has been published previously (Scharfman, 1992).

bria stimulation. Five mossy cells that were impaled also produced no spontaneous depolarization shifts and no response to fimbria stimulation.

\section{NMDA receptor antagonists}

D-APV was bath applied to nine slices $(25 \mu \mathrm{M}, n=3 ; 50 \mu \mathrm{M}, n$ $=6$ ) in which a granule cell was monitored intracellularly at the same time as area CA3 was recorded extracellularly. In these experiments, fimbria-evoked EPSP amplitude and half-duration did not change (control amplitude, $5.3 \pm 2.0 \mathrm{mV}$; amplitude in D-APV, $5.9 \pm 1.3 \mathrm{mV}$; control half-duration, $54 \pm 18 \mathrm{msec}$; duration in D-APV, $60 \pm 19 \mathrm{msec}$; paired $t$ tests, $p>0.05$ ). There was no detectable effect on duration of the pyramidal cell cpilcptiform burst, mcasurcd from fimbria-cvokcd bursts as the amplitude and duration of the positivity upon which population spikes appeared (amplitude in control, $5.9 \pm 2.9 \mathrm{mV}$; amplitude in D-APV, $6.0 \pm 2.1 \mathrm{mV}$; duration in control, $101 \pm 21 \mathrm{msec}$; duration in D-APV, $92 \pm 19 \mathrm{msec}$; paired $t$ tests, $p>0.05$ ). However, afterdischarges that occurred in control conditions disappeared after exposure to D-APV. When afterdischarges were blocked, the small granule cell depolarizations that had occurred at the same time as the afterdischarges also disappeared. The limited effects of D-APV on bicuculline-induced epileptiform bursts are similar to the results of other studies of NMDA receptor antagonists on epileptiform bursts in area CA3 induced by GABA antagonists (Schneiderman and MacDonald, 1989; Lee and Hablitz, 1990).

\section{Cholinergic antagonists}

Cholinergic antagonists were bath applied while recording from a granule cell and area CA3. Coapplication of the cholinergic muscarinic antagonist atropine and nicotinic antagonist mecamylamine had no effect ( $25 \mu \mathrm{M}$ each, $n=5$; data not shown). In three separate experiments, co-application of the muscarinic antagonist pirenzipine and the nicotinic antagonist dihydro- $\beta$ erythroidine also had no effect ( $25 \mu \mathrm{M}$, data not shown).

\section{The origin of granule cell EPSPs in disinhibited slices}

The results described above demonstrated that pyramidal cell bursts preceded mossy cell bursts and that mossy cell bursts preceded granule cell bursts. Taken together with the known projection of pyramidal cells to the hilus (Ishizuka et al., 1990; Li et al., 1994) and mossy cells to the molecular layer (Zimmer, 1971; Swanson et al., 1978, 1981; Laurberg and Sørensen, 1981; Ribak et al., 1985; Frotscher et al., 1991), the data suggest that granule cell EPSPs were due to area CA3 pyramidal cell excitation of mossy cells that in turn excited granule cells. Several experiments were performed to test this hypothesis.

\section{Extracellular recordings}

If mossy cells mediated granule cell EPSPs, then the extracellularly recorded EPSP corresponding to granule cell EPSPs should be maximal in the inner molecular layer, the site of the mossy cell axon plexus. Therefore, extracellular potentials were re- 

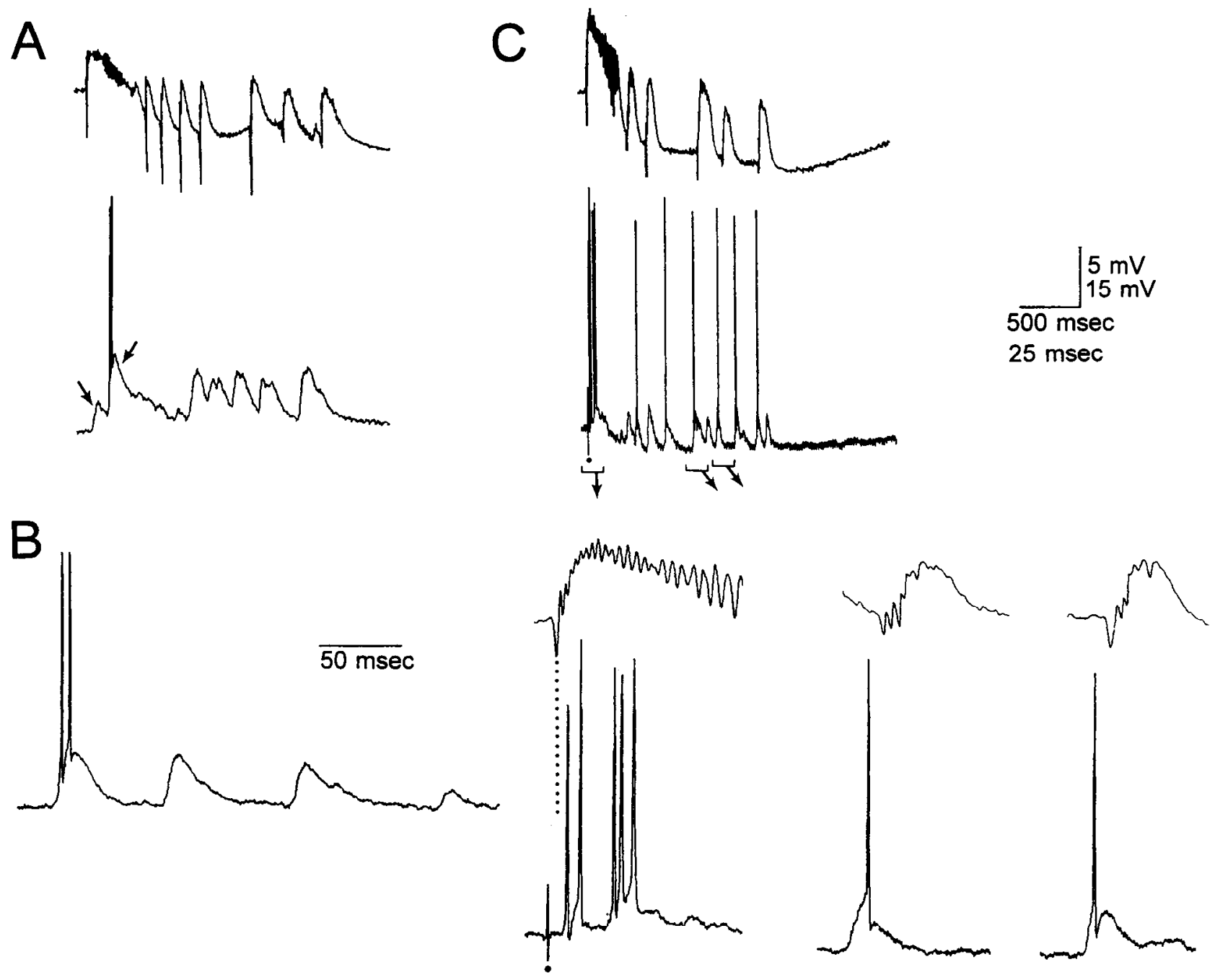

Figure 9. Examples of multiple EPSPs occurring in granule cells during epileptiform bursts of area CA3. A, A simultaneous recording of a spontaneous epileptiform burst of area CA3b (top) and a granule cell EPSP (bottom). Note that the EPSP occurring after the first discharge of pyramidal cells consisted of two distinct components (arrows). Bicuculline $(25 \mu \mathrm{M})$ and saclofen $(500 \mu \mathrm{M})$ were present. Calibration (in $C$ ): extracellular, $5 \mathrm{mV}, 500 \mathrm{msec}$; intracellular, $15 \mathrm{mV}, 500 \mathrm{msec}$. Granule cell membrane potential $=-65 \mathrm{mV}$; resting potential $=-75 \mathrm{mV} . B$, Repetitive depolarizations in a granule cell from a different slice. Voltage calibration (in $C), 15 \mathrm{mV}$. Bicuculline $(25 \mu \mathrm{M})$ and saclofen (250 $\mu \mathrm{M})$ were present. Granule cell membrane potential $=-60 \mathrm{mV}$; resting potential $=-79 \mathrm{mV}$. $C$, Simultaneous recording of a fimbria-evoked burst in area CA3c and a granule cell. The parts of the top traces in brackets are shown below with an expanded time base (calibration, $25 \mathrm{msec}$ ). Stimulation occurred at the dot. Note that for some of the later afterdischarges, granule cell EPSPs peaked before the onset of the afterdischarge. Bicuculline (25 $\mu \mathrm{M})$ was present but not saclofen. Granule cell membrane potential $=-61 \mathrm{mV}$; resting potential $=-82 \mathrm{mV}$.

corded in 33 slices throughout the granule cell layer and molecular layer in response to fimbria stimulation. Recordings were also made in area CAl and area CA3c, since the large field potentials in those areas could influence the field potentials in the dentate gyrus.

Figure 11 shows representative field potentials recorded in a slice exposed to bicuculline. A small positivity, sometimes with a 1-2 $\mathrm{mV}$ population spike, was recorded in the granule cell layer (Fig. 11). This population spike could reflect the large population spikes in area $\mathrm{CA} 3$, or it could reflect granule cells with EPSPs that sometimes reached threshold. The latter is most likely, since the largest CA3 population spike, which always occurred first, was not detected by the recording electrode in the granule cell layer (Fig. 11).

A negativity was recorded in the inner molecular layer, and this negativity decreased and reversed polarity as the recording electrode was moved toward the outer molccular layer (Fig. 11). These potentials are what one would expect if the negativity reflected a population EPSP of granule cells generated in the inner molecular layer. However, the onset of the negativity was complex, consisting of a mixed positive and negative potential (Fig. 11). This suggests that the field potential did not reflect a simple population EPSP. Another reason for hesitation is that large positive potentials were recorded near the fissure in area CAl (Fig. 11), and they could have contributed to the positivities recorded in the outer molecular layer. However, the field potentials recorded in the upper blade were similar to those recorded in the lower blade (data not shown), suggesting that area $\mathrm{CAl}$ activity was not responsible for field potentials in the molecular layer.

In summary, extracellular recordings supported the hypothesis that mossy cells were responsible for granule cell EPSPs 

A CONTROL

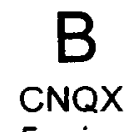
CNQX
5 min

\section{D \\ WASH}$$
10 \text { min }
$$
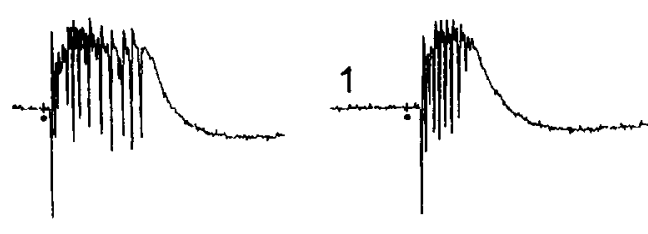

2
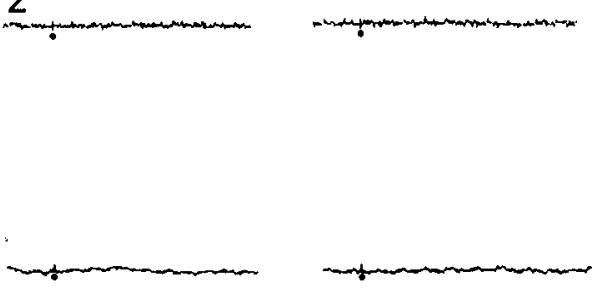

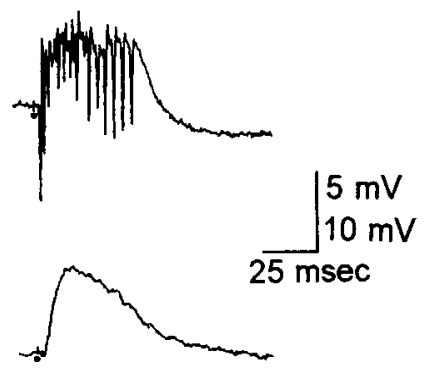

Figure 10. The bicuculline-induced epileptiform burst of area CA3 and the EPSP of granule cells is blocked by the AMPA/kainate receptor antagonist CNQX. $A$, Simultaneous recordings are shown from the area CA3a pyramidal cell layer (top) and a granule cell (bottom) in the presence of bicuculline $(25 \mu \mathrm{M})$ and saclofen $(500 \mu \mathrm{M})$. Fimbria stimulation (at the dot) evoked an epileptiform burst in the pyramidal cell layer and an EPSP in the granule cell. $B$, Two consecutive responses to the same fimbria stimulus as in $A$ are shown, evoked 5 min after CNQX was added to the perfusate. Stimulation either produced a relatively brief burst and relatively small EPSP (1), or no response (2). Whenever a small burst occurred, a small EPSP was recorded simultaneously in the granule cell, and whenever no burst occurred, no EPSP was detected in the granule cell. $C$, Stimulation evoked no response in the pyramidal cell layer or the granule cell after $10 \mathrm{~min}$ of bath application of CNQX. $D$, The blockade of the burst and EPSP reversed after wash in buffer containing bicuculline but not CNQX.

recorded in the presence of bicuculline. However, the complex nature of the field potentials mandates that the data be treated with caution.

\section{Focal application of $C N Q X$ and $A P V$}

If mossy cells were responsible for granule cell EPSPs, then it should be possible to block those effects by focal application of the appropriate antagonist at the site of innervation, the inner molecular layer. Therefore, the effects of focal application of CNQX were tested in five experiments. Bicuculline was bath applied first, and a granule cell was subsequently impaled to record its EPSP simultaneous to an extracellular recording from area CA3. A pipette containing $25 \mu \mathrm{M}$ CNQX was then placed in the inner molecular layer, within $100 \mu \mathrm{m}$ of the impaled granule cell. Figure 12 shows a representative experiment in which focal application of CNQX reduced the granule cell EPSP reversibly, without affecting the field potential recorded in area CA3. The same result was obtained in four other slices; the average decrease in the granule cell EPSP amplitude was 45.4 $\pm 2.3 \%$. The EPSP was never blocked completely. The effect of CNQX occurred within one second of ejection, and the amount of CNQX applied was not visible with an ocular micrometer when the pipette tip was raised in the air (see Materials and Methods). Therefore, it is likely that the drug acted within the molecular layer, rather than diffusing to distant sites. There were no changes in input resistance or membrane potential of the sampled cells during or immediately after ejection of CNQX. When D-APV was applied in a similar manner, there was no detectable effect on the EPSP; the concentration of D-APV in the pressure pipette was $100 \mu \mathrm{M}(n=3)$.

If pyramidal cell excitation of mossy cells was critical for granule cell EPSPs, then one would predict that block of pyramidal cell excitation of mossy cells would also block granule cell EPSPs. This was tested by applying CNQX to the hilar region while monitoring a granule cell EPSP and area CA3 extracellularly. In four slices, small amounts of CNQX were applied focally to several sites in the hilus (Fig. 13). In two slices there was no effect of CNQX application to any of five sites. In the other two slices, "hot spots" were found where a short du- ration pressure pulse to one site, but no other site, rapidly decreased the granule cell EPSP with recovery within seconds of ejection (Fig. 13).

These data support the hypothesis that two AMPA/kainate receptor-mediated synapses, one in the hilus and one in the molecular layer, contribute to granule cell EPSPs. These data support, but do not prove, the hypothesis that EPSPs are generated by pyramidal cells innervating mossy cells and mossy cells innervating granule cells.

\section{Severing slices between area $C A 3$ and the dentate gyrus}

Another method used to examine the dependence of granule cell EPSPs on pyramidal cell inputs was to sever the slice between area $\mathrm{CA} 3$ and the dentate gyrus. For these experiments, a cut was made between the lateral tips of the upper and lower blades of the dentate gyrus with a microscissors immediately after the dissection (Scharfman, 1994b). In brief, field potentials were recorded in the dentate gyrus in response to perforant path stimulation, and large field potentials $(>5 \mathrm{mV}$ population EPSP) with strong paired-pulse inhibition (complete suppression of the population spike when interstimulus interval was less than 20 msec) were one criterion used to accept slices for study. Another criteria was a $>5 \mathrm{mV}$ antidromic and single orthodromic population spike recorded from area $\mathrm{CA} 3 \mathrm{~b}$ in response to fimbria stimulation. After accepting a slice for study, a granule cell was impaled and area CA3b was recorded extracellularly. After ensuring that the cell was similar in its membrane properties to cclls in control slices, bicuculline was bath applied. In all six slices tested, area CA3b began to burst spontaneously and in response to fimbria stimulation, similar to control slices bathed in bicuculline. However, granule cells did not produce spontaneous or fimbria-evoked EPSPs. Molecular layer stimulation produced robust responses in granule cells but did not evoke any potentials in area CA3b. Mossy cells $(n=3)$ were subsequently impaled in these slices and demonstrated no depolarization shifts. However, large depolarizations were recorded from all mossy cells in response to molecular layer stimulation, indicating that their perforant path input was intact and that the slice had not deteriorated. These results support the hypothesis 


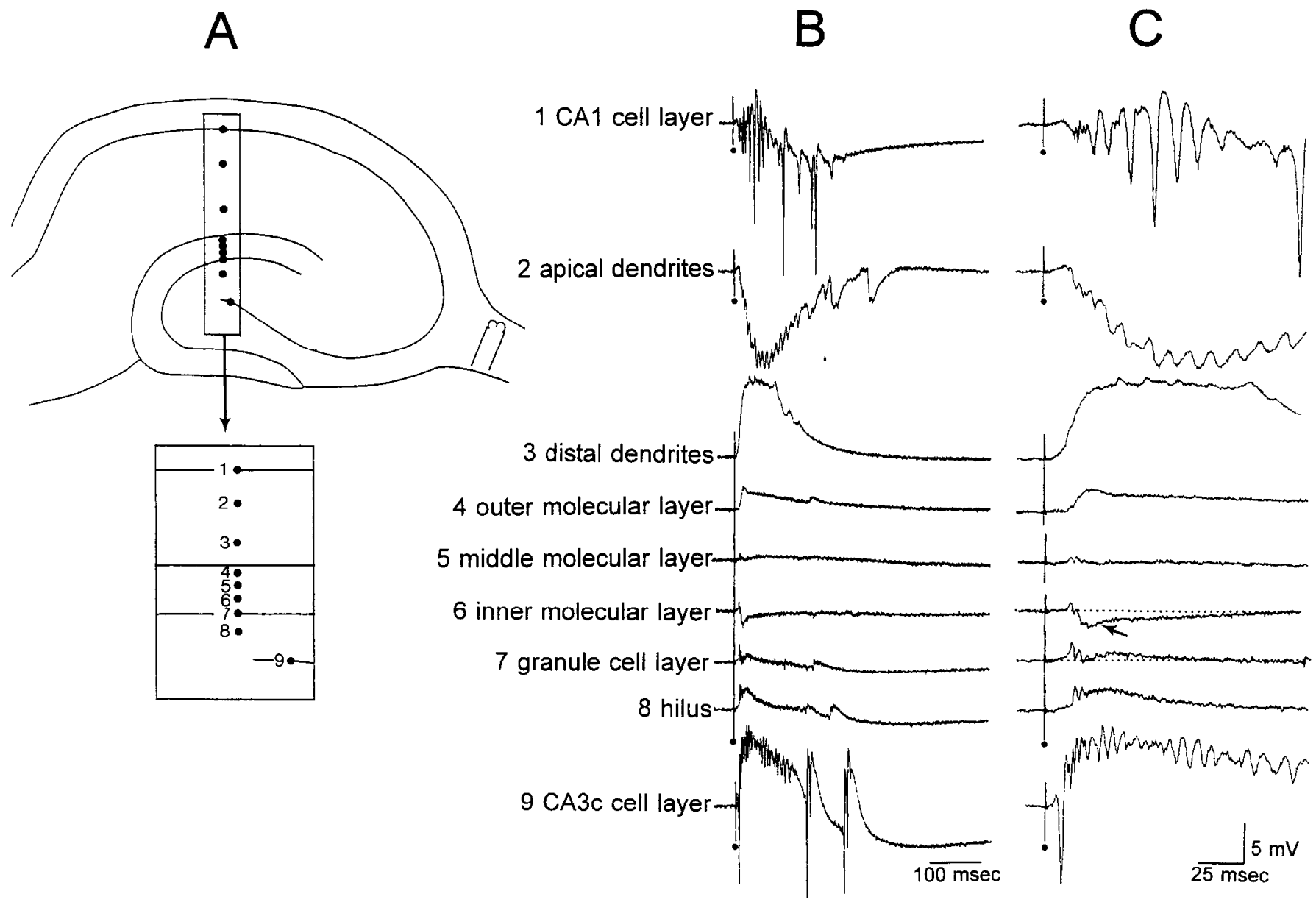

Figure 11. Extracellular rccording of pyramidal cell and granule cell ficld potentials in a slice perfused with bicuculline (25 $\mu \mathrm{M}) . A$, A schematic illustrates the area of the slice where recordings shown in $B$ and $C$ were taken. Each dot indicates a recording site. $B$ and $C$, Responses to the same fimbria stimulus are shown at a compressed $(B)$ and expanded $(C)$ time base. Fimbria stimulation evoked epileptiform bursts in areas CA1 and CA3 and mixed potentials were recorded in the dentate gyrus. Note that there was a negativity recorded extracellularly in the inner molecular layer (arrow) and a positivity in the granule cell layer and outer molecular layer. Similar potentials were recorded in the lower blade, so the dentate field potentials are unlikely to be merely a reflection of activity in area CA1. Stimulus artifacts are marked by the dots.

that epileptiform bursts begin in area CA3 and lead to excitatory activity in the dentate gyrus. They also indicate that mossy cells are unlikely to be one of the cell populations that initiate epileptiform bursts. Finally, the results suggest that the isolated dentate gyrus does not support epileptiform bursting in bicuculline.

\section{Discussion}

\section{Summary}

The results demonstrated that dentate granule cells depolarize during epileptiform bursts of area CA3 pyramidal cells and dentate hilar mossy cells in disinhibited slices. A hypothesis was presented to account for the granule cell depolarizations, namely, that whenever a burst discharge in area CA3 occurs, pyramidal cclls cxcite mossy cells, which in turn excite granule cells. Several experiments were performed to test this hypothesis and the results obtained supported it. Further experiments will be required to prove the hypothesis definitively.

Characteristics of spontaneous and evoked EPSPs generated in disinhibited granule cells

$V$ ariation with membrane potential. EPSPs were maximal between approximately -50 and $-65 \mathrm{mV}$. EPSPs occurring when the cell was at its resting potential were small and did not reach threshold. Thus, the EPSPs appeared to be limited by the intrinsic properties of granule cells, namely, the high resting potential where input resistance is relatively low and time constant is short. By extension, one would predict that this EPSP should be particularly sensitive to effects of neuromodulators or other inputs that could depolarize the cell, change its input resistance or change its time constant. One caveat is that the somatic recordings used in this study might not reliably record the events occurring at the site of synaptic input, on dendrites or dendritic spines. However, given that the electrotonic length of granule cells is relatively long (Brown et al,, 1981; Durand et al., 1983; Turner and Schwartzkroin, 1983), and the input is likely to be proximal (the inner molecular layer, as discussed below), somatic recordings would not necessarily be misleading.

Pharmacology. EPSPs were blocked by bath application of the AMPA/kainate receptor antagonist CNQX and decreased by focal application of CNQX to the molecular layer or the hilus. The inability of focal application to block the EPSP completely is likely to be the result of inadvertently placing the pressure pipette at some distance from the relevant synapses, so that antagonist concentration was low at the relevant receptors. However, it is also possible that other receptor subtypes 


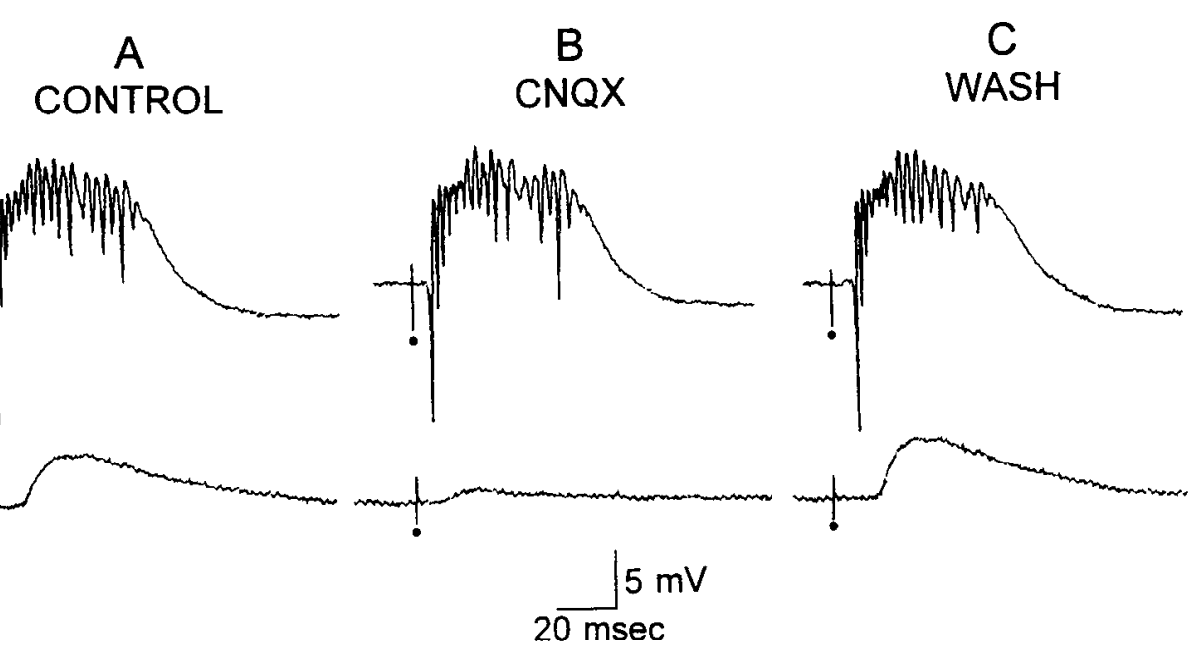

Figure 12. Focal application of CNQX to the inner molecular layer reduced fimbria-evoked EPSPs of granule cells. $A$, Simultaneous recordings from the area CA $3 c$ pyramidal cell layer (top) and a granule cell (bottom) are shown in the presence of bicuculline $(25 \mu \mathrm{M})$ and saclofen $(250 \mu \mathrm{M})$. Stimulation of the fimbria occurred at the dots. Granule cell membrane potential $=-70 \mathrm{mV}$; resting potential $=-76 \mathrm{mV} . B$, One second after CNQX ejection into the inner molecular layer, the response of the granule cell was reduced, but no difference was apparent in the area CA3 recording. CNQX was ejected approximately 50 $\mu \mathrm{m}$ from the intracellular electrode. The concentration of CNQX in the pipette was $25 \mu \mathrm{M}$; pulse pressure was $18 \mathrm{lb} /$ square inch and pulse duration was 250 msec. $C$, Responses to the same fimbria stimulus as in $A$ and $B$ are shown. The stimulus was triggered approximately 5 sec after CNQX ejection. contribute to the EPSP besides CNQX-sensitive receptors. In light of this possibility, it was important to show that the NMDA receptor antagonist APV had no detectable effect on granule cell EPSPs, although if lower concentrations of extracellular magnesium had been employed, an APV-sensitive component might have been detected. It is also significant that cholinergic receptor antagonists had no detectable effects. A possibility that remains is that peptidergic neurons contributed to granule cell EPSPs; such effects would be blocked by bath application of CNQX if pyramidal cells excited those neurons by CNQX-sensitive receptors.

It is also possible that nonsynaptic mechanisms contribute to the EPSPs. Because CNQX bath application blocked pyramidal cell bursts, a nonsynaptic effect of those bursts would be blocked by CNQX and yet it could still contribute to granule cell EPSPs. Therefore, it is important that focal application of CNQX could reduce the EPSP without altering the large field potentials close by, in area CA3c. Nevertheless, because focal application never blocked the EPSP completely, nonsynaptic mechanisms may contribute to the EPSP. Specifically, ephaptic interactions are a candidate, especially given the inability of intracellular current injection to increase granule cell EPSP amplitude. Gap junctions among any of the participating neural populations are also possible. Gap junctions have been reported among granule cells, although very rarely (MacVicar and Dudek, 1982). Anatomical studies have only reported gap junctions among interneurons (Katsumaru et al., 1988).

Spontaneous and fimbria-evoked EPSPS were weakly excitatory. Spontaneous and fimbria-evoked EPSPs appeared to be weakly excitatory because they rarely evoked discharge. In addition, they were similar to the EPSPs produced by weak stimulation of the perforant path. They differed in several respects from EPSPs evoked by strong stimulation of the perforant path.

The interpretation that the EPSPs examined in this study were due to mossy cell input to granule cells (see below), and that the effect of this input was weakly excitatory, echo the studies of others who have examined the effects of hilar stimulation on contralateral granule cells in vivo. The excitatory effects of hilar stimulation in these studies were probably due to mossy cells, since mossy cells are the only hilar cells that are known to be immunoreactive for glutamate and project to the contralateral inner molecular layer (Swanson et al., 1978, 1981; Laurberg and Sorensen, 1981; Bakst et al., 1986; Soriano and Frotscher, in press). Stimulation in control conditions produced inhibitory cffcets in vivo (Douglas ct al., 1983; Bilkey and Goddard, 1987) but weakly excitatory effects after systemic bicuculline (Douglas et al., 1983). Such effects are similar to the results of the present study, where in control conditions there was no evidence of mossy cell excitation of granule cells, and fimbria stimulation was actually inhibitory (Fig. 5); in the presence of bicuculline, mossy cells appeared to weakly excite granule cells. A hypothesis uniting these findings was proposed by Sloviter, who suggested that hilar mossy cells may primarily excite inhibitory interneurons that act at $\mathrm{GABA}_{\mathrm{A}}$ receptors, with only weak excitation of granule cells (Sloviter, 1991).

Excitation of granule cells compared to interneurons. Recent studies showed that interneurons in both the hilus and the granule cell layer discharge repetitively, sometimes on depolarization shifts, in the presence of bicuculline (Scharfman, 1994b). These depolarizations followed those of pyramidal cells by sevcral milliscconds (Scharfman, 1994b). In the present study, mossy cells were recorded simultaneous to interneurons to determine which cell type discharged first. In seven of nine cases, the mossy cell's first action potential occurred immediately before the onset of the interneuron depolarization. These data suggest that the same excitatory pathway that activates granule cells may also excite dentate interneurons, that is, excitation spreads from area CA3 to mossy cells and then to interneurons. This conclusion is in agreement with evidence from anatomical studies that commissurally projecting hilar neurons innervate basket cells as well as granule cells (Seress and Ribak, 1984).

Since discharge of interneurons was always greater than that of granule cells, and interneurons demonstrated depolarization shifts in some cases whereas that was not true of granule cells, it appeared that the excitation of interneurons was greater than that of granule cells. Such preferential excitation of interneurons by mossy cclls has been predicted (Sloviter, 1991). However, since the data presented here were collected in a slice preparation, the strength of excitation of interneurons may merely reflect better preservation of inputs onto interneurons as com- 


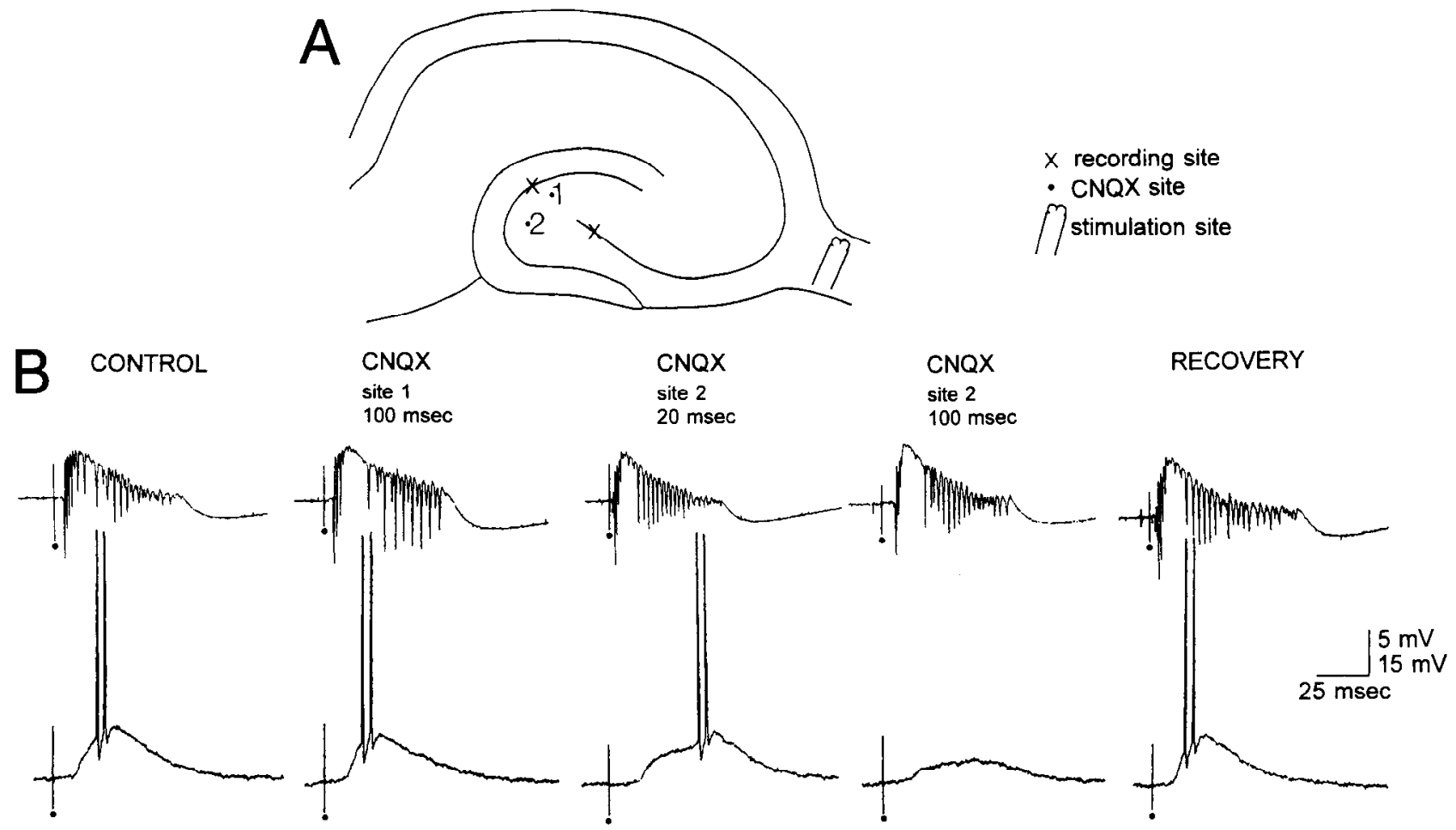

Figure 13. Focal application of CNQX to the hilus reduced fimbria-evoked EPSPs of granule cells. $A$, A schematic illustrates where recording, stimulating, and CNQX-filled electrodes were placed in the slice for the recordings in $B$. Recording electrodes were placed in a granule cell and extracellularly in the area CA3c pyramidal cell layer. Fimbria stimulation was used to evoked granule cell EPSPs in bicuculline (10 $\mu \mathrm{M})$ and saclofen $(500 \mu \mathrm{M})$. The first site of CNQX application is marked by a dot and labeled 1 ; the second site is labeled 2 . $B$, Simultaneous recordings from the area CA3c pyramidal cell layer and a granule cell. In control, an EPSP and two action potentials were evoked in response to a fimbria stimulus. After a $100 \mathrm{msec}$ pressure pulse of $\mathrm{CNQX}$ at site 1 (see $A$ ), there was no detectable change in either the response in area CA3 or in the granule cell. However, after a $20 \mathrm{msec}$ and $100 \mathrm{msec}$ pulse at site 2, there was a decrease in the EPSP evoked by the fimbria stimulus. However, there was no detectable change in the epileptiform burst in area CA3. On the far right, responses to the same stimulus are shown 5 sec after the 100 msec pulse of CNQX at site 2, showing that the CNQX effect was reversible. Dots mark stimulus artifacts. CNQX concentration in the pipette, $25 \mu \mathrm{M}$; pressure, $18 \mathrm{lbs}$ /square inch. Granule cell membrane potential $=-60 \mathrm{mV}$; resting potential $=-84 \mathrm{mV}$.

pared to granule cells. Furthermore, given the heterogeneity of interneurons in the dentate gyrus (Amaral, 1978; Hu et al., 1993), it is premature to generalize that the excitatory pathway in disinhibited slices will always be stronger with respect to interneurons than granule cells.

\section{Evidence that a pyramidal cell $\rightarrow$ mossy cell $\rightarrow$ granule cell circuit underlies granule cell EPSPs}

The hypothesis raised by the results is that spontaneous and fimbria-evoked EPSPs of granule cells in disinhibited slices are due to discharges of pyramidal cells and mossy cells. Specifically, it is proposed that pyramidal cells excite mossy cells and mossy cells depolarize granule cells. AMPA/kainate receptors mediate excitation at each synapse. A small contribution by nonsynaptic mechanisms may also occur.

Support for the hypothesis. The following points outline how the data support this hypothesis. (1) Granule cell EPSPs were always produced when pyramidal cells and mossy cells burst. For example, stimulus strengths required to elicit bursts in pyramidal cells and mossy cells were the same as those that were necessary to evoke granule cell EPSPs. When triggered too frequently, stimuli that failed to producc bursts also failed to produce EPSPs. (2) Pyramidal cells and mossy cells started their epileptiform bursts before the onset of granule cell EPSPs. Specifically, pyramidal cell bursts began several milliseconds before granule cell EPSPs and mossy cell bursts began immediately before granule cell EPSPs. (3) Pharmacological sensitivity of pyramidal cell and mossy cell bursts was the same as granule cell EPSPs (CNQX sensitive, APV insensitive, and unresponsive to cholinergic antagonists). (4) CNQX positioned at the likely point of pyramidal cell innervation of mossy cells, or mossy cell innervation of granule cells, decreased EPSPs. (5) Severing the slice between area $\mathrm{CA} 3$ and the dentate gyrus blocked granule cell FPSPs. (6) The extracellularly recorded EPSP was maximal in the inner molecular layer.

The results of other studies also support the hypothesis. Anatomical studies have shown that pyramidal cell axon collaterals are found in the hilus (Ishizuka et al., 1990; Li et al., 1994), and that pyramidal cells use an excitatory amino acid as a neurotransmitter (Cotman and Nadler, 1981; Ottersen and StormMathisen, 1987). Many studies have shown that mossy cells innervate the inner molecular layer (Amaral, 1978; Ribak et al., 1985; Frotscher et al., 1991), even within the confines of a hippocampal slice (Buckmaster et al., 1992), and mossy cells appear to be glutamatergic (Storm-Mathisen and Wold, 1981; Soriano and Frotscher, in press). There is no evidence at the present time that any other glutamatergic cell type that would be present in a slice innervates granule cells. Physiological evidence also supports the hypothesis, because in the presence of bicuculline, hilar stimulation has been found to cause weak excitation of granule cells by others (as discussed above).

Arguments against the hypothesis. Although there is support 


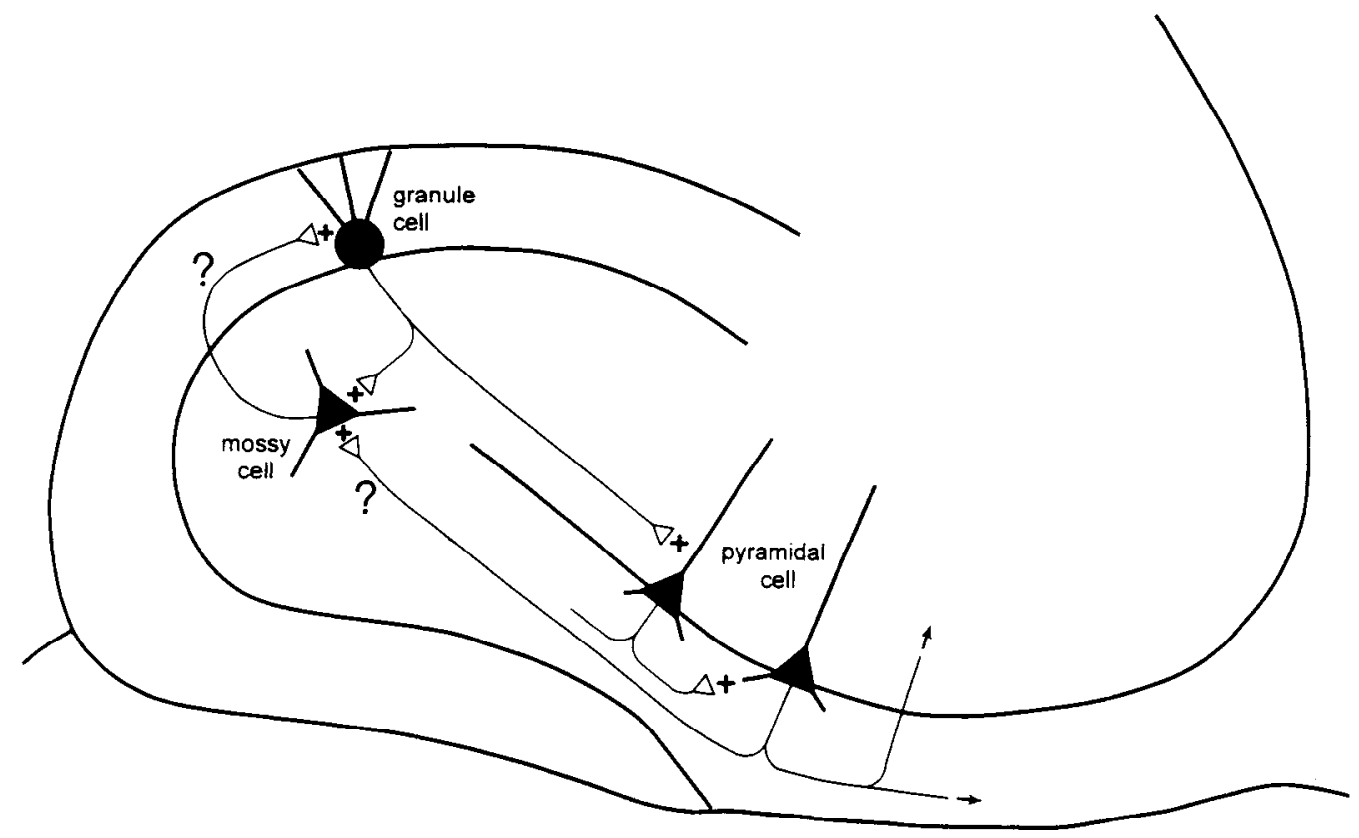

Figure 14. A possible excitatory pathway between area CA3 pyramidal cells, dentate hilar mossy cells, and dentate granule cells. A simplified diagram is shown of the pathway suggested by the results. It is proposed that pyramidal cells excite mossy cells and that mossy cells excite granule cells, although this pathway may only be operative during blockade of $\mathrm{GABA}_{\mathrm{A}}$ receptor-mediated inhibition. It is likely that recurrent excitation among pyramidal cells is required because several milliseconds often elapsed between burst onsets of pyramidal cells and mossy cells (Scharfman, 1994b). In addition, not all pyramidal cells collateralize in the hilus (Ishizuka et al., 1990). For clarity, only some of the cell populations in the hippocampus and dentate gyrus and only some of the dendrites and axons of cells are depicted.

for a pyramidal cell $\rightarrow$ mossy cell $\rightarrow$ granule cell pathway, there also are reasons to hesitate making such a conclusion. For example, focal application of CNQX to the hilus and to the inner molecular layer did not completely block granule cell EPSPs. As mentioned above, one reason for this might be the inability to predict exactly where in the inner molecular layer the relevant synapses are, and apply an adequate concentration of CNQX exactly at those sites. It is also possible that a nonglutamatergic, noncholinergic transmitter generates the granule cell EPSPs, such as a peptide. Alternatively, depolarizations may be generated by ephaptic interactions and/or gap junctions.

Another problem is the small and complex nature of the extracellularly recorded negativity recorded in the inner molecular layer during pyramidal cell burst discharges. Although the data suggested that a granule cell EPSP might be generated in the inner molecular layer, the small amplitude and complexity of interpreting field potentials in slices where most areas generate burst discharges weakens the ability of those experiments to support the hypothesis.

The fact that granule cells did not always depolarize during pyramidal cell afterdischarges is another problem. There was exact correspondence between pyramidal cells and mossy cells in the number of afterdischarges (Scharfman, 1994b), but granule cells did not produce an EPSP after every pyramidal cell atterdischarge. A way to reconcile this result with the proposed hypothesis is to postulate that extremely strong excitation of pyramidal cells and mossy cells is required to produce granule cell EPSPs, and while PDSs produce enough excitation, afterdischarges do not. However, there also could be an as yet undiscovered element in the circuitry that dissociates pyramidal cell discharges from granule cell EPSPs. For example, there may be a non-GABAergic inhibitory cell. If such a cell type were innervated by pyramidal cells or mossy cells, it would become particularly important when pyramidal cells and mossy cells produce burst discharges, since the cell would be excited more strongly than in control conditions.

Another possibility is that recurrent excitatory circuits within area CA3 are interposed between granule cell excitation of CA3 and CA3 excitation of the dentate gyrus. Such polysynaptic circuits in area CA3 might cause a variable delay between one granule cell EPSP following one afterdischarge and the next EPSP. There are two other reasons to suggest this. First, there was a substantial latency between the onset of pyramidal cell epileptiform bursts and granule cell EPSPs in somc cascs, more than could be attributed to two synapses. Second, many pyramidal cells do not project to the dentate gyrus (Ishizuka et al., 1990) but they do excite each other (Miles and Wong, 1986).

In summary, the data suggest that an excitatory pathway originating in area CA3 and acting via mossy cells causes EPSPs in granule cells when inhibition is suppressed. However, contributions by other mechanisms cannot be ruled out completely. This pathway is evidently completely suppressed when GABAergic inhibition is intact, and may require both a loss of inhibitory inputs to granule cells as well as synchronous activation of excitatory cells (area CA3 pyramidal cells and hilar mossy cells) for its expression; further experiments will be necessary to address such issues.

\section{Summary}

Regardless of the mechanisms underlying the excitation produced in granule cells in disinhibited slices, it is noteworthy that excitation occurs and that it closely follows population bursts in area CA3 and hilar mossy cells. This is significant because it indicates a direction of excitation that flows in the opposite direction of the trisynaptic circuit.

The existence of an excitatory pathway from area CA3 py- 
ramidal cells to dentate granule cells may also have implications for seizure activity and epileptogenesis in the hippocampus. Since granule cells innervate pyramidal cells, an excitatory pathway from area CA3 to dentate granule cells theoretically completes a positive feedback loop (Fig. 14) that could lead to rhythmic, synchronized discharge among pyramidal cells and granule cells. Since the excitatory pathway from area CA 3 to the dentate gyrus appears to act via mossy cells, and granule cells innervate mossy cells, a second positive feedback loop theoretically exists between granule cells and mossy cells (Fig. 14). Such pathways could activate large populations of hippocampal and dentate neurons in vivo, since pyramidal cell and mossy cell axons are interlamellar and project commissurally (Amaral and Witter, 1989). This hypothesis is supported by the observation in this study of repetitive EPSPs in granule cells, and the observation that afterdischarges of pyramidal cells appeared to follow the later granule cell EPSPs. Complete blockade of inhibition is critical to this positive feedback circuit, because partial disinhibition of granule cells and pyramidal cells might produce a paradoxical increase in inhibitory tone as inhibitory interneurons would be excited more than usual; indeed, there is evidence for such a paradoxical increase in inhibition when the concentration of bicuculline is low (Scharfman, 1994a).

Although such circuitry could contribute to epileptiform activity, it is unlikely to explain seizure activity in temporal lobe epilepsy, because in most cases of temporal lobe epilepsy hilar cells and CA3 pyramidal cells have degenerated (hippocampal sclerosis). Yet it is tempting to speculate that this circuitry could contribute to the development of such a disease, because sustained activity in the circuit could be potentially excitotoxic to hilar cells and pyramidal cells, and therefore contribute to hippocampal sclerosis. Thus, the results not only demonstrate a direction of excitation within the hippocampus that proceeds in the opposite direction of the trisynaptic circuit, but they also suggest a novel pathway that could contribute to seizure sensitivity, generation, and propagation within the hippocampus.

\section{References}

Amaral DG (1978) A Golgi study of cell types in the hilar region of the hippocampus in rat. J Comp Neurol 182:851-914.

Amaral DG, Witter M (1989) The three-dimensional organization of the hippocampal formation: a review of anatomical data. Neuroscience 31:571-591.

Andersen P, Bliss TVP, Skrede KK (1971) Lamellar organization of the hippocampal excitatory pathways. Exp Brain Res 13:222-238.

Bakst I, Avendano C, Morrison JH, Amaral DG (1986) An experimental analysis of origins of somatostatin-like immunoreactivity in dentate gyrus of rat. J Neurosci 6:1452-1462.

Bilkey DK, Goddard GV (1987) Septohippocampal and commissural pathways antagonistically control inhibitory interneurons in the dentate gyrus. Brain Res 405:320-325.

Brown TH, Fricke RA, Perkel DH (1981) Passive electrical constants in three classes of hippocampal neurons. J Neurophysiol 46:812-827.

Buckmaster PS, Strowbridge BW, Kunkel DD, Schmiege DL, Schwartzkroin PA (1992) Mossy cell axonal projections to the dentate gyrus molecular layer in the rat hippocampal slice. Hippocampus 2:349362.

Collingridge GL, Kehl SJ, McLennan H (1984) The action of some analogues of the excitatory amino acids in the dentate gyrus of the rat. Can J Physiol Pharmacol 62:424-429.

Cotman CW, Nadler JV (1981) Glutamate and aspartate as hippocampal transmitters: biochemical and pharmacological evidence. In: Glutamate: transmitter in the central nervous system (Roberts PJ, Storm-Mathisen J, Johnston GAR, eds), pp 117-154. New York: Wiley.

Dahl D, Burgard EC, Sarvey JM (1990) NMDA receptor antagonists reduce medial, but not lateral perforant path-evoked EPSPs in dentate gyrus of rat hippocampal slice. Exp Brain Res 83:172-177.

Dichter M, Spencer WA (1969) Penicillin-induced interictal discharges from the cat hippocampus. I. Characteristics and topographical features. J Neurophysiol 32:649-662.

Dingledine R, Gjerstad L (1980) Reduced inhibition during epileptiform activity in the in vitro hippocampal slice. J Physiol (Lond) 305:297-313.

Douglas RM, McNaugton BL, Goddard GV (1983) Commissural inhibition and facilitation of granule cell discharge in fascia dentata. $J$ Comp Neurol 219:285-294.

Durand D, Carlen PL, Gurevich N, Ho A, Kunov H (1983) Electrotonic parameters of rat dentate granule cells measured using short current pulses and HRP staining. J Neurophysiol 50:1080-1097.

Fricke RA, Prince DA (1984) Flectrophysiology of dentate gyrus granule cells. J Neurophysiol 51:195-209.

Frotscher M, Seress L, Schwerdtfeger WK, Buhl E (1991) The mossy cells of the fascia dentata: a comparative study of their fine structure and synaptic connections in rodents and primates. $\mathbf{J}$ Comp Neurol 312:145-163.

Habliz JJ (1984) Picrotoxin-induced epileptiform activity in hippocampus: role of endogenous versus synaptic factors. J Neurophysiol 51:1011-1027.

Hu Z-S, Buhl EH, Lörinczi Z, Somogyi P (1993) A high degree of spatial selectivity in the axonal and dendritic domains of physiologically identified local-circuit neurons in the dentate gyrus of the rat hippocampus. Eur J Neurosci 5:395-410.

Ishizuka N, Weber J, Amaral DG (1990) Organization of intrahippocampal projections originating from CA3 pyramidal cells in the rat. J Comp Neurol 295:580-623.

Jeffreys JGR (1981) Influence of electric fields on the excitability of granule cells in guinea-pig hippocampal slices. J Physiol (Lond) 319: 143-152.

Katsumaru H, Kosaka T, Heizmann CW, Hama K (1988) Gap junctions on GABAergic neurons containing the calcium-binding protein parvalbumin in the rat hippocampus (CAl region). Exp Brain Res 72:363-370.

Keller BU, Konnerth A, Yaari Y (1991) Patch clamp analysis of excitatory synaptic currents in granule cells of rat hippocampus. J Physiol (Lond) 435:275-293.

Köhler C, Eriksson LG, Davies S, Chan-Palay V (1987) Colocalization of neuropeptide tyrosine and somatostatin immunoreactivities in neurons of individual hippocampal subfields in rat. Neurosci Lett 78: $1-6$.

Kosaka T, Kosaka K, Tateishi K, Hamaoka Y, Yanaihara N, Wu J-Y, Hama K (1985) GABAergic neurons containing CCK-8-like and/ or VIP-like immunoreactivities in the rat hippocampus and dentate gyrus. J Comp Neurol 239:420-430.

Lambert JDC, Jones RSG (1990) A reevaluation of excitatory amino acid-mediated synaptic transmission in rat dentate gyrus. J Neurophysiol 64:119-132.

Laurberg S, Sørensen KE (1981) Associational and commissural collaterals of neurons in the hippocampal formation (hilus fasciae dentatae and subfield CA3). Brain Res 212:287-300.

Lee W-L, Hablitz JJ (1990) Effect of APV and ketamine on epileptiform activity in the $\mathrm{CA} 1$ and $\mathrm{CA} 3$ regions of the hippocampus. Epilepsy Res 6:87-94.

Li X-G, Somogyi P, Ylinen A, Buzsáki G (1994) The hippocampal CA3 network: an in vivo intracellular labeling study. J Comp Neurol 33:181-208.

Livsey CT, Vicini S (1992) Slower spontaneous excitatory postsynaptic currents in spiny versus aspiny hilar neurons. Neuron 8:745-755.

MacVicar BA, Dudek FE (1982) Electrotonic coupling between granule cells of rat dentate gyrus: physiological and anatomical evidence. J Neurophysiol 47:579-592.

Miles R, Wong RKS (1986) Excitatory synaptic interactions between $\mathrm{CA} 3$ neurons in the guinea pig hippocampal slice. J Physiol (Lond) 373:397-418.

Müller W, Misgeld U (1991) Picrotoxin- and 4-aminopyridine-induced activity in hilar neurons in the guinea pig hippocampal slice. J Neurophysiol 65:141-147.

Otis TS, Staley KJ, Mody I (1991) Perpetual inhibitory activity in mammalian brain slices generated by spontaneous GABA release. Brain Res 545:142-150.

Ottersen O, Storm-Mathisen J (1987) Excitatory and inhibitory amino 
acids in the hippocampus. In: The hippocampus, new vistas (ChanPalay V, Köhler C, eds), pp 97-118. New York: Liss.

Ramón y Cajal, S (1911) Histologie du système nerveux de l'homme et des vertébrés. Paris: Maloine.

Ribak CE, Seress L (1983) Five types of basket cell in the hippocampal dentate gyrus: a combined Golgi and electron microscopic study. J Neurocytol 12:577-597.

Ribak CE, Seress L, Amaral DG (1985) The development, ultrastructure, and synaptic connections of the mossy cells of the dentate gyrus. J Neurocytol 14:835-857.

Richardson TL, Turner RW, Miller JJ (1984) Extracellular fields influence transmembrane potentials and synchronization of hippocampal neuronal activity. Brain Res 294:255-262.

Roper SN, Obenaus A, Dudek FE (1992) Osmolality and nonsynaptic epileptiform bursts in rat CA1 and dentate gyrus. Ann Neurol 31:8185 .

Scharfman HE (1992) Differentiation of rat dentate neurons by morphology and electrophysiology in hippocampal slices: granule cells, spiny hilar cells, and aspiny "fast-spiking" cells. In: The dentate gyrus and its role in seizures (Ribak CE, Gall CM, Mody I, eds), pp 93109. Amsterdam: Elsevier.

Scharfman HE (1993a) Activation of dentate hilar neurons by stimulation of the fimbria in rat hippocampal slices. Neurosci Lett 156: 61-66.

Scharfman IIE (1993b) Characteristics of spontaneous and evoked EPSPs recorded from dentate spiny hilar cells in rat hippocampal slices. J Neurophysiol 70:742-757.

Scharfman HE (1993c) Excitation and inhibition of dentate hilar cells and dentate granule cells in response to fimbria stimulation in rat hippocampal slices. Soc Neurosci Abstr 19:351.

Scharfman HE (1994a) Paradoxical enhancement by bicuculline of dentate granule cell IPSPs evoked by fimbria stimulation in rat hippocampal slices. Neurosci Lett, in press.

Scharfman HE (1994b) Synchronization of area CA3 hippocampal pyramidal cells and non-granule cells of the dentate gyrus in bicuculline-treated rat hippocampal slices. Neuroscience 59:245-257.

Scharfman HE, Schwartzkroin PA (1988) Electrophysiology of morphologically-identified dentate hilar "mossy" cells in rat hippocampal slices. J Neurosci 8:3812-3821.

Scharfman HE, Kunkel DD, Schwartzkroin PA (1990) Synaptic connections of dentate granule cells and hilar neurons: results of paired intracellular recordings and intracellular horseradish peroxidase injections. Neuroscience 37:693-707.

Schneiderman JH, MacDonald JF (1989) Excitatory amino acid blockers differentially affect bursting of in vitro hippocampal neurons in two pharmacological models of epilepsy. Neuroscience 31:593-603.

Schwartzkroin PA, Prince DA (1977) Penicillin-induced epileptiform activity in the hippocampal in vitro preparation. Ann Neurol 1:463469.
Seress L, Ribak CE (1984) Direct commissural connections to the basket cells of the hippocampal dentate gyrus: anatomical evidence for feed-forward inhibition. J Neurocytol 13:215-225.

Sloviter RS (1991) Permanently altered hippocampal structure, excitability, and inhibition after experimental status epilepticus in that rat: the "dormant basket cell" hypothesis and its possible relevance to temporal lobe epilepsy. Hippocampus 1:41-66.

Sloviter RS, Nilaver G (1987) Immunocytochemical localization of GABA-, cholecystokinin-, vasoactive intestinal polypeptide-, and somatostatin-like immunoreactivity in the area dentata and hippocampus of the rat. J Comp Ncurol 256:42-60.

Snow RW, Dudek FE (1984) Electrical fields directly contribute to action potential synchronization during convulsant-induced epileptiform bursts. Brain Res 323:114-118.

Soriano E, Frotscher M (in press) Mossy cells of the rat fascia dentata are glutamate-immunoreactive. Hippocampus, in press.

Storm-Mathisen J, Wold JE (1981) In vivo high affinity uptake and axonal transport of $\mathrm{D}-\left[2,3-{ }^{3} \mathrm{H}\right]$ aspartate in excitatory neurons. Brain Res 230:427-435.

Swann JW, Brady RJ, Friedman RJ, Smith EJ (1986) The dendritic origins of penicillin-induced epileptogenesis in CA3 hippocampal pyramidal cells. J Neurophysiol 56:1718-1738.

Swann JW, Smith KL, Brady RJ (1993) Localized excitatory synaptic interactions mediate the sustained depolarization of electrographic seizures in developing hippocampus. J Ncurosci 13:4680-4689.

Swanson LW, Wyss JM, Cowan WM (1978) An autoradiographic study of the organization of intrahippocampal association pathways in the rat. J Comp Neurol 181:681-710.

Swanson LW, Sawchenko PE, Cowan WM (1981) Evidence for collateral projections by neurons in Ammon's horn, the dentate gyrus, and the subiculum: a multiple retrograde labeling study in the rat. $\mathbf{J}$ Neurosci 1:548-559.

Taylor CP, Krnjevíc K, Ropert N (1984) Facilitation of hippocampal CA3 pyramidal cell firing by electrical fields generated antidromically. Neuroscience 11:101-109.

Turner DA, Schwartzkroin PA (1983) Electrical characteristics of dendrites and dendritic spines in intracellularly stained CA3 dentate hippocampal neurons. J Neurosci 3:2381-2394.

Wong RKS, Traub RD (1983) Synchronized burst discharge in disinhibited hippocampal slice. I. Initiation in CA2-CA3 region. J Neurophysiol 49:442-458.

Yeckel MF, Berger TW (1990) Feedforward excitation of the hippocampus by afferents from the entorhinal cortex: redefinition of the role of the trisynaptic pathway. Proc Natl Acad Sci USA 87:58325836.

Zimmer J (1971) Ipsilateral afferents to the commissural zone of the fascia dentata, demonstrated in decommissurated rats by silver impregnation. J Comp Neurol 142:393-416. 